\title{
FANTAZJA I PRZEMOC WYOBRAŹNI RELIGIJNEJ: ISLAMOFOBIA I ANTYSEMITYZM WE FRANCJI I AFRYCE PÓŁNOCNEJ.
}

\author{
PAUL A. SILVERSTEIN
}

PRZEŁOŻYłA: NELLY STREHLAU

\begin{abstract}
Abstrakt: Tekst jest próbą prześledzenia zmian we francuskiej retoryce antyislamskiej oraz osadzenia ich w szerszym kontekście (post)kolonialnej historii francuskiej polityki asymilacyjnej. Autor wychodzi od pytania o związek łączący przemoc z formowaniem się kategorii etniczno-religijnej różnicy, by wyjaśnić, w jaki sposób kształtowała się polityczna i kulturowa tożsamość francuskich wspólnot muzułmańskich. Współczesna islamofobia i przemoc skierowana przeciwko Arabom, przejawiające się zarówno w dyskursie medialnym, jak i w polityce państwa, zostają zestawione z dyskursem antysemickim, w którym kwestia asymilacji odgrywa równie ważną rolę. Zdaniem autora islamofobiczne i antysemickie narracje dotyczące zdolności danej grupy do asymilacji służą do kreślenia linii demarkacyjnej pomiędzy tymi grupami etnicznymi, które dają się zaliczyć w poczet narodowej wspólnoty (utożsamianej z francuskim państwem), oraz tymi, które postrzegane są jako z samej swej natury obce.
\end{abstract}

Słowa kluczowe: islamofobia, antysemityzm, Francja, Afryka północna, asymilacja, przemoc, państwo 
W szczególnie poruszającej scenie głośnego filmu Mathieu Kassovitza La Haine (Nienawiść, 1995) - posępnego, neorealistycznego obrazu marginalizacji i przemocy w blokowiskach [les cités] na przedmieściach [banlieues] Paryża - główny bohater, biały Żyd imieniem Vinz, próbuje wyjaśnić Saïdowi, swemu bliskiemu kumplowi, muzułmaninowi z Afryki Północnej, swoja fantazję o zabójstwie policjanta, którego dokona, jeśli umrze ich wspólny przyjaciel, Abdel, ofiara policyjnej przemocy.

Vinz: Chcesz być następnym Arabem [rebeu] zabitym na posterunku policji?

Saï: Nie.

Vinz: No, ja też nie.

Saï: Ty też nie? Ty nie chcesz być następnym Arabem zabitym na posterunku policji?

Vinz: Dokładnie...

Dziesięć lat później w filmie La Petite Jérusalem w reżyserii Karin Albou przedstawione zostały pęknięcia takich przekraczających etniczne i religijne podziały wyobrażeń. Film ten, którego akcja osadzona jest w innym peryferyjnym cité Paryża, opowiada zupełnie inną historię dojrzewania. Nie jest to historia młodych mężczyzn próbujących przeżyć w cieniu policyjnej przemocy, lecz młodej ortodoksyjnej Żydówki Laury, która próbuje manewrować pomiędzy „religijnym prawem” swojej społeczności, studiowaniem Kantowskiej filozofii oraz rosnącym pożądaniem seksualnym, jakie odczuwa do muzułmanina, Djamela, uchodźcy z dotkniętej przeciagająca się wojną domową Algierii. O ile film Kassovitza w samoświadomy sposób przedstawia bajkę klasowo-przestrzennej solidarności, której emblematem jest przedstawienie się Vinza jako „Araba”, film Albou, którego akcja toczy się w pierwszych latach dwudziestego pierwszego wieku, w trakcie serii ataków na synagogi i Żydów we Francji, pokazuje - poprzez nieudany związek Djamela i Laury oraz emigrację jej rodziny do Izraela - że realizacja takich wyobrażeń przekraczających podziały etniczne i religijne jest ostatecznie niemożliwa.

Być może najlepszym sposobem podejścia do tego, co w niniejszym zbiorze określa się jako ,islamofobię” i ,islamofilię” etniczno-religijnej różnicy w ramach i poprzez historię przemocy. Podobnie jak w przypadku mężczyzn pochodzenia afroamerykańskiego w Stanach Zjednoczonych, we współczesnych mediach francuskich i dyskursie politycznym młodzi francuscy muzułmanie z cités sa demonizowani jako kulturowo skłonni do przemocy, seksizmu, homofobii i antysemityzmu (Guénif-Soulaimas i Macé 2003), choć jednocześnie ich sposób ubierania się i mówienia, jak

\footnotetext{
1 Tekst pochodzi ze zbioru Islamophobia and Islamophilia. Beyond the Politics of Enemy and Friend pod redakcja Andrew Shryocka (2010); Bloomington-Indianapolis: Indiana University Press [przyp. red.].
} 
i formy muzyczne zawłaszczane są jako stylistyka oporu przez niemuzułmańską młodzież $\mathrm{w}$ banlieues, a nawet w burżuazyjnych centrach miast. O ile zwiększające się ostatnio tempo konwersji na islam w blokowiskach $i$ francuskich więzieniach ${ }^{2}$ wskazuje na potencjalne tworzenie się mody na tę religię, przedstawianej lokalnie jako religia protestu społecznego (Daynes 1999; Lakhdar i in. 2007) - podobnie jak w sytuacji, która opisuje Hisham Aïdi w odniesieniu do Stanów Zjednoczonych i Ameryki Lacińskiej (2002; 2003) - to ta domniemana „islamizacja” banlieues wywołuje alarmistyczne zaniepokojenie wzrostem islamskiego fundamentalizmu oraz coraz częstsze przedstawianie podmiejskich blokowisk jako przestrzeni „dżihadu” (Pujadas i Salam 1995), jako „utraconych terytoriów Republiki” (Brenner 2002) czy jako forpoczt islamskiego imperium „Eurabii” (Bat Ye’or 2005).

Dynamikę islamofobii i islamofilii we Francji trzeba osadzić w kontekście niedawnej debaty dotyczącej francuskiego „nowego antysemityzmu”. Zestawiając rosnącą liczbę antysemickich ataków we Francji z pierwszych lat dwudziestego pierwszego wieku z „klasycznym antysemityzem”, którego związki z prawicowymi przejawami nacjonalizmu francuskiego dokładnie omawia Zeev Sterhnell (1986), wielu niedawnych komentatorów w tym Emmanuel Brenner (2002), Raphaël Dradï (2001), Alain Finkielkraut (2003), PierreAndré Taguieff (2004) i Shmuel Trigano (2003) - łączy „,nowy antysemityzm” z postępowym zwrotem ku islamskiej polityce tożsamości mającym miejsce wśród dzieci imigrantów z Afryki Północnej (lub osób pochodzenia franko-maghrebskiego). Choć autorzy ci starają się odróżniać islamizm od islamu, twierdzą oni, że antysemityzm francuskich muzułmanów stanowi kontynuację starszego muzułmańskiego antysyjonizmu i antysemityzmu importowanego z Afryki Północnej przez imigrantów, przenoszonego z rodziców na dzieci i tolerowanego przez państwo, które nie chce urazić swoich mniejszości oraz arabskich partnerów dyplomatycznych (Brenner 2002, 14; Taguieff 2004, 14-15)3. U Trigano $(2003,91)$ ta ocena prowadzi do całościowego potępienia społeczności „arabsko-muzułmańskiej”, która potrzebuje gruntownej reformy, o ile ma wpasować się w nowoczesny, świecki świat (zob. Dradi 2001, 191). Podobnie jak Bat Ye'or (2002; 2005) autorzy ci przypisuja europejskim muzułmanom polityczną chęć ponownego ustanowienia ponadnarodowego kalifatu, w którym mniejszości takie jak Żydzi traktowane byłyby jako dhimmis i pozostawałyby zależne od kaprysów suwerena - co Trigano (2003, 106-180) nazywa „ottomanizacją Europy”. Postrzegają oni bowiem tę odnowioną ottomańską formę rządów jako już istniejącą na przedmieściach, które Finkielkraut (2003, 10) charakteryzuje jako „ziemie zdziczałe” [lieux

\footnotetext{
${ }^{2}$ Raporty francuskiego wywiadu państwowego sugeruja, że we Francji mogło dojść nawet do 100000 nawróceń, i donoszą, że muzułmanie stanowią do 50\% populacji więziennej (Smith 2004; Whitlock 2006).

${ }^{3}$ Należy zwrócić uwagę, że choć kategoria „francuskich muzułmanów” (Français musulmans lub Musulmans en/de France) nominalnie zawiera w sobie muzułmanów pochodzących z Afryki Subsaharyjskiej, Turcji lub Południowej Azji wraz z osobami nawróconymi na islam, francuskie media i rząd skupiają się na Francuzach pochodzenia północnoafrykańskiego, uważanych za najbardziej podatnych na nauki islamistyczne (da'wa) i najbardziej odpowiedzialnych za raportowany wzrost antysemityzmu.
} 
féroces], na których polityczne normy demokracji i państwowego sekularyzmu [laïité] po prostu nie istnieja.

W odróżnieniu od wymienionych autorów sytuuję muzułmanów i Żydów we Francji w ramach tego samego pola analitycznego i podchodzę do przemocy, jaka wiąże się $z$ antysemityzmem, islamofobią i islamofilią, łącznie, traktując ją jako część pewnego zestawu strukturalnych napięć późnej francuskiej nowoczesności - napięć pomiędzy partykularyzmem i uniwersalizmem, pomiędzy prawami jednostki a prawami ogół ${ }^{4}$. Napięcia te są zakorzenione we francuskiej postkolonialności, w nierozstrzygniętych, wciąż trwających bataliach o francuską przynależność narodowa, mających swoje źródło w kolonizacji Afryki Północnej, a dokładniej w gorzkiej wojnie dekolonizacyjnej, która dosłownie rozdarła Republikę Francuską. Pamięć przemocy przeniosła się wraz z emigracją robotników z Afryki Północnej i ich rodzin do Francji, zaś to, że wielu muzułmańskich obywateli francuskich ciagle doświadcza rasizmu i marginalizacji, wskazuje, że opis manichejskiego świata dokonany przez Frantza Fanona (1985) w późnokolonialnej Algierii nadal trafnie ujmuje współczesną rzeczywistość. Marginalizacja ta zaostrzyła się w ostatnich latach z powodu francuskiej „wojny z terroryzmem", która poprzedza 11 września i sięga korzeniami wczesnych lat dziewięćdziesiątych. Strach przed przeniesieniem algierskiej wojny domowej na francuską ziemię doprowadził wtedy do postępującej sekurytyzacji blokowisk, w których mieszka wielu młodych ludzi pochodzenia franko-maghrebskiego, oraz do związanego z tym nasilenia się konfliktu pomiędzy policją i młodzieżą z blokowisk. Co więcej, ta „wojna z terroryzmem” skutkuje w dużej mierze interpelacją (w Althusserowskim znaczeniu tego terminu) osób ze społeczności franko-maghrebskiej jako „muzułmanów”, która wspomagana jest także przez histerię wokół hidżabu i wprowadzonego niedawno zakazu jego noszenia w szkołach publicznych (zob. Asad 2006; Auslander 2000; Beriss 1990; Bowen 2006; Killian 2003; Moruzzi 1994; Scott 2007; Silverstein 2004a). Podczas gdy poprzednie pokolenie franko-maghrebskich aktorów społecznych i politycznych - z ruchu „Beurów” z lat osiemdziesiątych - ograniczało swój aktywizm głównie do poprawiania własnej sytuacji życiowej jako obywateli Francji

\footnotetext{
${ }^{4}$ Równoległą analizę i krytykę dyskursu „nowego antysemityzmu” jako formy „nowej islamofobii” zawiera artykuł Geissera (2003, 77-93). Podobny sceptycyzm można też znaleźć u Balibara i innych (2003) oraz u Vidala (2003). W swoim przekrojowym badaniu antysemickich poglądów we Francji Michel Wieviorka (2007) i jego zespół badawczy formułuja zrównoważoną analizę, która zarazem rozpoznaje wyzwania społeczne stawiane przez wzrost antysemityzmu we Francji i ostrzega przed poddawaniem się panice moralnej, wzniecanej przez takich autorów jak Brenner, Finkielkraut, Taguieff i Trigano. Mój esej podąża tropem tego projektu. Omówienie ról, które odpowiednio antysemityzm i islamofobia odgrywają w przesuwających się pozycjach nacjonalizmu i pannacjonalizmu w szerszym kontekście Europy zawierają: Bunzl 2005, a także różne komentarze, które pojawiły się po wydaniu tego artykułu i podkreślały szerszą kolonialna/postkolonialną dynamikę różnych rasizmów. Krytyczne omówienia dotyczące stosowności używania terminów „(nowy) antysemityzm” i „,islamofobia” w odniesieniu do aktualnego rasizmu wymierzonego w żydów i muzułmanów we Francji znaleźć można w tekstach autorów takich jak Bowen (2005, 524), Peace (2008, 118-121), Wieviorka (2007, 62-68). „Antysemityzm” odnosi się zasadniczo do starszej typologii rasowej, w której Żydzi (jak i Arabowie) byli napiętnowani jako „semici”. W ,islamofobii” problemem jest raczej psychologiczny strach przed religia islamska, nie zaś strukturalna dyskryminacja i urasowiony dyskurs skierowany przeciwko muzułmanom. Tym niemniej są to terminy, do których odnosi się debata we Francji, i w takim kontekście używam ich w tym eseju.
} 
i mieszkańców zaniedbanych obszarów podmiejskich, a inspiracji szukało w walce toczonej przez czarnych Amerykanów i Afrykanów z RPA (zob. Derderian 2004; Hargreaves 1995), pokolenie młodsze - działające jako „muzułmanie” i na ogół odcinające się od etnonimu „Beur” - kieruje swoja polityczna świadomość raczej ku okupacji Iraku lub przemocy w Izraelu/Palestynie jako wyraźnym analogiom ich własnej sytuacji we Francji. To w tym kontekście postawa owej grupy wobec państwa francuskiego jako siły nieustannie kolonizującej może przyjąć formę uogólnionego antysyjonizmu i okazjonalnego antysemityzmu, w ramach którego, jakże ironicznie, Żydzi są uznawani (poprzez błędne skojarzenie ich z żołnierzami izraelskimi) za wzór francuskiego mieszczańskiego sukcesu i islamofobicznych praktyk. Jak twierdzą Michel Wieviorka i jego współpracownicy:

\begin{abstract}
Żydzi w Izraelu zachowują się w stosunku do Palestyńczyków tak, jak „Francuzi” we Francji zachowują się w stosunku do „ludzi z Afryki Północnej” [...]. W atmosferze rasizmu i charakterystycznego dla nich wykluczenia „Arabowie” są zatem uważani za ofiary podwójnie złego traktowania ze strony francuskich Żydów, którzy uciskają ich jako Żydzi, odtwarzając model stosunku Żyda izraelskiego do palestyńskiego Araba, oraz jako Francuzi, traktując ich w sposób rasistowski i pozbawiony szacunku (2007, 142-43).
\end{abstract}

Gwałtowne urasowienie imigrantów z Afryki Północnej i ich dzieci jako „muzułmanów” oraz przemoc ze strony państwa francuskiego, z którą się mierzą, znajduje czasem odpowiedź w przemocy skierowanej zwrotnie ku państwu i wobec tych (również Żydów), którzy wydaja się je reprezentować ${ }^{5}$. Porwanie i zamordowanie sprzedawcy telefonów komórkowych, francuskiego Żyda Ilana Halimiego w styczniu i lutym 2006 roku, stanowi pole do analizy tego, jak niejednoznaczna i złożona jest w praktyce ta przemocowa identyfikacja i dezidentyfikacja. W innych przypadkach społeczności muzułmańskie we Francji i Afryce Północnej - zwłaszcza aktywiści berberscy/Amazigh - angażują się w praktyki kontrastujące z wyobraźnią kulturową, identyfikują się $z$ prześladowanymi Żydami i przyjmują postawy filosemickie, proizraelskie, nawet islamofobiczne.

Kiedy odczytuję współczesną dynamikę islamofobii/islamofilii i antysemityzmu/ filosemityzmu jako części składowe szerszego konfliktu, stawiającego młodych francuskich muzułmanów, marginalizowanych pod względem społeczno-ekonomicznym, inwigilowanych i traktowanych jak podejrzani, naprzeciw francuskiego państwa, uwzględniam tylko pewien

\footnotetext{
${ }^{5}$ Należy zwrócić uwagę, że pomimo założeń pewnych islamofobicznych krytyków (zob. wywiad z Alainem Finkielkrautem w: Mishani i Smotriez 2005) nie każdy przypadek publicznej przemocy ze strony dzieci północnoafrykańskich imigrantów musi wynikać z logiki religijnej interpelacji i inwokacji. W październiku i listopadzie 2005 podczas fali przemocy w peryferyjnych blokowiskach Francji młodzi mężczyźni na ulicach organizowali się głównie według więzi wynikających z dzielonego miejsca zamieszkania i wspólnej marginalizacji społeczno-ekonomicznej, która wykraczała poza różnice etniczne i religijne. Wołania o spokój ze strony lokalnych stowarzyszeń islamskich, a nawet fatwa przeciwko przemocy wydana przez rzekomo fundamentalistyczny Związek Organizacji Islamskich we Francji (UOIF) trafiły w próżnię. Zob. Silverstein i Tetreault 2006.
} 
konkretny wymiar różnorodnej i pofragmentowanej natury antysemityzmu oraz islamofobii we Francji. Podobnie jak Wieviorka $(2007,13)$ nie definiuję tych zjawisk jako „homogenicznych lub spójnych”. Co więcej, wprost odsuwam tu na dalszy plan wyjaśnienia, które traktują wzajemną przemoc i fantazję wyłącznie jako kontynuację długotrwałego konfliktu wyznaniowego pomiędzy Żydami i muzułmanami. Nie twierdzę przy tym, że historyczne związki między tymi grupami w Afryce Północnej są zupełnie bez znaczenia dla tematu; jak ukazuję to poniżej, to rządy kolonialne zapewniły ramę pojęciowa, poprzez którą różne grupy zgłaszają roszczenia do francuskiej podmiotowości (Bahloul 1996; Benbassa 1999, 185-189; Hyman 1998, 193-214).

We Francji Żydzi i muzułmanie pochodzenia północnoafrykańskiego, zwłaszcza z pierwszego pokolenia, są w podobny sposób urasawiani jako ,imigranci” (zob. Silverstein 2005), zamieszkuja podobne miejsca i korzystają ze wspólnych miejskich usług oraz zasobów (takich jak rzeźnie z halal lub koszernymi produktami). Okazuje się jednak, że różnice w ich wspomnieniach z Algierii czasów kolonialnych i wojennych tworzą między nimi afektywny dystans (zob. Stora 1991). Stosunki pomiędzy nimi zaostrzały się w niektórych okresach, na przykład z powodu wojny w Izraelu/Palestynie w 1967 roku, zwłaszcza ze względu na zwrot społeczności Żydów algierskich ku Izraelowi jako głównemu źródłu politycznej identyfikacji (Hyman 1998, 202-205). Trwająca w Izraelu/Palestynie przemoc oraz fakt, że wielu Arabów i Berberów z Afryki Północnej (w wyniku wojny domowej w Algierii i francuskiej wojny z terroryzmem) identyfikuje się przede wszystkim jako muzułmanie, wbijaja kolejny klin pomiędzy te społeczności, zwiększając wyczulenie Żydów z Afryki Północnej na kwestię antysemickiej retoryki i przemocy, a nawet kształtując ich podobne reakcje ${ }^{6}$.

Jednakże ta konkretna genealogia współczesnego konfliktu religijnego jest znacznie mniej istotna dla młodych osób pochodzenia franko-maghrebskiego, urodzonych i wychowanych we Francji po algierskiej wojnie o niepodległość. Ich historyczna świadomość kolonialnej przemocy w Algierii pozostaje raczej ograniczona (Stora 2006) i od 2003 roku przejawia się w formie mobilizacji przeciw propozycjom zmian w prawie, w ramach których wprowadzono wymóg nauczania o „pozytywnej roli kolonializmu”, jak również w głosach domagających się od Francji wzięcia odpowiedzialności za handel niewolnikami; czy w powstaniu ruchu Indigènes de la République, angażującego początkowo elitę lub wykształcony czy zaktywizowany margines młodych muzułmanów z blokowisk. Z tego powodu błędem byłoby postrzegać fantazję i przemoc młodych wyłącznie przez pryzmat konfliktów o podłożu religijnym,

\footnotetext{
6 Od 2002 roku rzeczywiście nastąpił znaczący wzrost liczby ataków wymierzonych w Arabów i muzułmanów, przeprowadzanych przez Żydów pochodzących z Afryki Północnej, czy to mających miejsce w sferze publicznej, na wiecach poparcia dla Izraela, czy poza nią, jak w przypadkach ataków ulicznych i palenia meczetów (Shatz 2005). O bardziej ogólnym wzroście liczby ataków antymuzułmańskich we Francji od późnych lat dziewięćdziesiątych - zob. Geisser 2003, 10-13.
} 
odziedziczonych po ich rodzicach, lub też dopatrywać się jakiejś jednolitości we wczorajszych i dzisiejszych walkach określanych mianem antyimperialnych. Tym niemniej, ponieważ konteksty Algierii czasów kolonialnych i wojennych stanowią kluczowe momenty widentyfikacji muzułmanów i Żydów z Afryki Północnej jako odmiennych podmiotów kategorialnych, pozostają one ważnym punktem wyjścia dla analizy.

\section{Kolonialne korzenie islamofobii}

Francuska kolonizacja Afryki Północnej pojmowana była przez wielu jej ideologów jako element szerszej powinności, w równej mierze „misja cywilizacyjna”, co ekspedycja militarna (zob. Colonna 1975; Cooper i Stoler 1997; Guilhaume 1992; Lucas i Vatin 1975; Rosenblum 1988, ale także Bullard 2000). Choć ta kontestowana i wysoce niejednoznaczna misja opierała się na rewolucyjnej, politycznej teorii uniwersalnego obywatelstwa, w praktyce rozegrała się ona znacznie bliżej tego, co Jean-Loup Amselle (2003, x) określił, odwołując się do Foucaulta (1998), mianem „wojny pomiędzy rasami”. W kolonialnej Afryce Północnej francuska administracja kolonialna rozróżniała formalnie obywateli europejskich od rodzimych poddanych (których nie nazywano „obywatelami”, ale „mieszkańcami kraju”, ang. nationals). Ten podział miał swoje formalne odbicie w code de l'indigénat, zgodnie z którym Żydzi do 1870 roku, a algierscy muzułmanie do roku 1958 pozbawieni byli prawa do obywatelstwa francuskiego i podlegali odrębnym systemom sądownictwa oraz kodeksom prawnym, co standaryzowała i czemu nadawała oficjalny status francuska administracja. Ogólnie rzecz ujmując, dostęp do obywatelstwa francuskiego wymagał od danej osoby zrzeczenia się „osobistego" religijnego lub „lokalno-cywilnego" statusu, co postrzegane było jako równoznaczne $z$ apostazją i wobec tego niemal powszechnie unikane. Jednak wewnątrz tego szerszego, urasawiającego podziału na obywatelstwo i „narodowość” francuscy kolonialni etnologowie dokonywali dalszych klasyfikacji w obrębie rodzimych populacji na podstawie cech kulturowych i jezzykowych, traktując je jako różnicujące możliwość asymilacji do projektu cywilizacyjnego (Ageron 1960; Lorcin 1995; Silverstein 2004b, 35-75). W Afryce Północnej badacze wojskowi - idąc w ślady takich luminarzy jak Alexis de Tocqueville (1991 [1937-1847]) - wielokrotnie reifikowali społeczeństwo arabskie jako przede wszystkim i głównie islamskie; zwracali też uwagę na brak kompatybilności między cywilizacją islamską i francuską (chrześcijańsko-świecka) nowoczesnością. W ten sposób maskowano lęki przed islamem jako jednocząca siła polityczna podczas antykolonialnych buntów w dziewiętnastym wieku; lęki ponownie podsycone w dwudziestym wieku przez arabskie ruchy nacjonalistyczne w Tunezji i Egipcie, które z kolei zaowocowały walką o algierską niepodległość.

W dyskursie kolonialnym islam był głównym trybem wyjaśniania dwóch przeciwstawnych cech domniemanej osobowości arabskiej: z jednej strony, „wojowniczej”, 
„wrogiej” natury Arabów, związanej rzekomo z ich religijnym „fanatyzmem”; a z drugiej strony, ich „nałogowego lenistwa”, wynikającego z bogobojnego „fatalizmu”. Po pierwsze, obserwatorzy francuscy twierdzili, że „absolutyzm” Arabów umieszcza ich w „stanie ciagłej wojny z niewiernymi, nakłada na nich obowiązek wiecznej wojny, która nie może zostać wstrzymana" (Servier 1923, 345-346). Islam służył jako główny czynnik wyjaśniający okrucieństwa wojny (ścięcia, tortury, okaleczenia) zaobserwowane przez francuskie siły ekspedycyjne podczas podboju Algierii, przypisywane „mściwej i okrutnej naturze” Arabów, „którzy nie znaja żadnego prawa, poza tym [narzuconym] przez najsilniejszego” (Hamelin 1833, 7). W badaniach prowadzonych przez etnografów wojskowych zwracano szczególną uwagę na te religijne organizacje algierskie, takie jak marabuci czy bractwo Sufi (khouan), które posiadały mistyczny autorytet i potencjalnie były w stanie popchnać wyznawców do przemocy (zob. de Neveu 1846; Rinn 1884).

Po drugie, badacze skupiali się na przeciwnym aspekcie islamu - „fatalizmie”, absolutnym poleganiu na Allahu w kwestii determinowania czyjejś przyszłości. Postrzegali oni ten fatalizm jako podstawowa przyczynę długiej listy wad [muzułmanów], takich jak „lenistwo, obłuda, podejrzliwość, nieprzewidywalność, zamiłowanie do lubieżności, luksusu i ucztowania [...]” (Van Vollenhoven 1903, 169), potępiając Araba-muzułmanina jako zawodowo „pijącego słońce” [buveur de soleil] (Docteur X 1891, 55). Uważano, że to bogobojne „lenistwo” osłabia intelekt muzułmanów, powstrzymując wszelki ruch społeczeństwa w stronę nowoczesności.

Co więcej, administracja francuska postrzegała tę zasadniczą religijność Arabów jako istotna przeszkodę w ich administracyjnej czy prawnej asymilacji do narodu francuskiego. „W cywilizacji mahometańskiej religia i prawo sa zbyt intymnie splątane, aby stan prawny muzułmanów był identyczny ze stanem Francuzów czy Europejczyków” (Larcher 1903, 16). Takie założenie doprowadziło do faktycznego zawieszenia lä̈ité w Algierii, chociaż kolonia ta oficjalnie stanowiła trzy départements d'outre-mer i wobec tego powinna była normalnie podlegać temu samemu reżimowi prawnemu i konstytucyjnemu co metropolia. Kiedy w 1891 roku, za czasów Trzeciej Republiki, rozważano wyeliminowanie tej ostatniej przeszkody i naturalizowanie wszystkich Algierczyków, w parlamencie wybuchła gwałtowna debata. Jeden z senatorów, Sabatier, zwracając się do senatu 27 czerwca 1891, sprzeciwił się reformie, gdyż wskazywała ona rzekomo na domniemaną akceptację „koranicznych” praktyk cywilnych i rodzinnych, od „feudalnego” zarządzania ziemią po „poligamię”, które miały „uchybiać prawom francuskim, by nie wspomnieć o francuskiej moralności” (cyt. za: Borgé i Viasnoff 1995, 18). Uwzględnianie religii przy przyznawaniu obywatelstwa zostało wyeliminowane dopiero po II wojnie światowej, niedługo przed uzyskaniem przez Algierię niepodległości.

Podczas gdy arabscy muzułmanie umieszczani byli w kategorii „,niemożliwych do zasymilowania”, francuscy uczeni kolonialni traktowali pewne populacje mniejszościowe zwłaszcza Żydów i Berberów - jako bliższe cywilizacji francuskiej. Wynikało to w dużej mierze 
z założenia, że praktyki kulturowe i życie społeczne tych grup nie były skoncentrowane wokół religii. Chociaż Żydom z Afryki Północnej, tak jak i muzułmanom, początkowo odmawiano obywatelstwa francuskiego, przyznano im potem prawa wyborcze w Algierii na mocy dekretu Crémieux z 1870; byli oni od tego czasu traktowani inaczej niż reszta skolonizowanej populacji. Podobnie Berberowie - choć nie otrzymali prawa głosu - byli grupa wielokrotnie wybierana przy próbach asymilacji (takich jak zakładanie francuskich szkół publicznych i misyjnych [Colonna 1975]), w sprawach cywilnych natomiast pozwalano im działać według systemu prawa zwyczajowego, nie zaś islamskiego. Preferowano ich również przy wyborze ludzi do pracy na kolonialnych farmach i w kopalniach, a także za granica, we Francji. Zgodnie z przekonaniem, które stało się później znane jako „mit kabylski” (Ageron 1960), naukowcy wojskowi twierdzili, że Berberowie, jako autochtoniczna ludność Afryki Północnej, ulegli jedynie powierzchownej islamizacji, są z natury świeccy, a w podejściu do pracy - „purytańscy”. Co więcej, w różnych momentach historii włączanie rodzimych mieszkańców kolonii do ciała politycznego Wielkiej Francji było obwoływane jako zbawienne dla narodu francuskiego, gdyż miało łagodzić stagnację w przyroście narodzin w metropolii, zapewniać potrzebnych żołnierzy i pracowników fabryk podczas kolejnych konfliktów w Europie i sprawiać, by Francuzi, zamiast przejawiać wyniszczająca dekadencję, stawali się znów bardziej „barbarzyńscy”7. Takie twierdzenia o zgodności Berberów z francuską nowoczesnością, czy o ich wkładzie w jej rozwój, powtarzają się w starciach pomiędzy islamofilią a berberofilią w czasach współczesnych, gdyż obecni aktywiści berberscy/Amazigh przedstawiają siebie i społeczności pochodzenia berberskiego, w imieniu których się wypowiadają, jako uosobienie rdzennej lä̈ité oraz wzór praktyki islamskiej, która pozostaje w zgodzie z wartościami Republiki Francuskiej i wspiera je.

Te podziały pomiędzy Arabami, Berberami i Żydami tworzyły się podczas walki o dekolonizację. Jako obywatele francuscy, Żydzi - choć wielu z nich sympatyzowało z algierskimi i marokańskimi nacjonalistami - w dużej mierze dążyli do zachowania jakiejś formy francuskiej Afryki Północnej. Podlegli oni niemal powszechnej „repatriacji” (by użyć retoryki państwa francuskiego) do Francji na koniec wojny algierskiej 1954-1962. Choć Arabowie i Berberowie walczyli razem przeciwko Francuzom, interesy tych dwóch grup w dużej mierze przestały być zbieżne w toku walki o dekolonizację: elity berberskie wzywały do stworzenia wieloetnicznego i wielowyznaniowego niezależnego państwa, zaś arabscy przywódcy Narodowego Frontu Wyzwolenia (FLN) w Algierii i Partii Istiqlal w Maroku pragnęli utworzyć narody arabsko-islamskie (Duclos 1972; Stora 1991). Wizje Istiqlal i FLN osiagnęły później status hegemoniczny, zaś wielu przywódców algierskich Berberów zostało

\footnotetext{
${ }^{7}$ Akademik Louis Bertrand (1930 [1889], 8-13) w otwarty sposób wyrażał swoje fantazje na temat „nowej rasy łacińskiej”, stworzonej przez złączenie się osadników francuskich i Berberów, których „barbarzyństwo” miało „tchnąć nowe życie” w cywilizację francuską i doprowadzić do „narodowej regeneracji”.
} 
wygnanych, zamordowanych lub zmarginalizowanych za swoje domniemane tendencje separatystyczne oraz za bycie kolonialnymi „pachołkami”, co przejawiało się w ich naciskaniu na kulturową różnorodność Afryki Północnej (Lacheraf 1953; Sahli 1953; zob. Chaker 1990).

Wojny rozgrywające się w Maroku i w Algierii miały reperkusje we Francji, gdzie pracowało kilkaset tysięcy mężczyzn z Afryki Północnej (z których wielu było Berberami), mieszkających albo w hotelach robotniczych, albo - w okresie, gdy narastała przemoc w Algierii - z żonami i dziećmi w dzielnicach nędzy. Podczas wojny imigranci byli obiektem ostrej inwigilacji, ich stowarzyszenia i organizacje były uznawane za grupy przestępcze, zdarzały się też przypadki represji policyjnych, na przykład po wiecu poparcia dla FLN 17 października 1961 w Paryżu, kiedy to oddziały prewencyjne policji otworzyły ogień do maszerujących Algierczyków; zginęły setki osób, których ciała wrzucono do Sekwany (Einaudi 2001; Haroun 1986). Policja znajdowała się wtedy pod bezpośrednią kontrolą Maurice’a Papona, byłego urzędnika wysokiej rangi reżimu Vichy. Jak potem wyszło na jaw, był on odpowiedzialny za deportację tysięcy francuskich Żydów do obozów koncentracyjnych i obozów zagłady w nazistowskich Niemczech, zaś później, gdy był już gubernatorem Konstantyny we wschodniej Algierii, wykazał się poprzez wprowadzenie reżimu sankcjonowanych przez państwo tortur, które stosowane były wobec członków rodzącego się ruchu narodowego Algierii. W tym sensie państwowa przemoc wobec Żydów i muzułmanów jest połączona historycznymi i intymnymi więzami.

\section{Przemoc postkolonialna}

Pod koniec wojny we Francji żyło około 400000 osób pochodzenia północnoafrykańskiego. We wczesnych latach osiemdziesiątych liczba ta wzrosła do około 1,5 miliona: było to skutkiem rosnącej w szybkim tempie migracji zarobkowej (do roku 1974), jak i późniejszej polityki jednoczenia rodzin, która ułatwiła przybycie do Francji żonom i dzieciom imigrantówmężczyzn ${ }^{8}$. Do imigracji tej obserwatorzy francuscy odnosili się w sposób ambiwalentny, na zmianę ujmując ją jako wkład w życie narodu lub przemoc, używając motywu „inwazji”, by opisać obecność imigrantów z Afryki Północnej w kraju, zwłaszcza w okresach spowolnienia gospodarczego, które miały miejsce w latach trzydziestych, w połowie lat siedemdziesiątych i od połowy lat dziewięćdziesiątych (Wihtol de Wenden 1991). Jako że Karol Młot, jak twierdzą francuskie podręczniki historii, powstrzymał Saracenów w bitwie pod Poitiers w 732 roku, dzisiejsza imigracja z Afryki Północnej zostaje zrekonstruowana przez pewnych autorów snujących apokaliptyczne wizje jako zemsta Saracenów, czy to jako „inwazja pokojowa”, czy też uzbrojona w kałasznikowy (Raspail 1973; Figueras 1983). I rzeczywiście, naukowcy

\footnotetext{
${ }^{8}$ Historię i analizę algierskiej imigracji we Francji można znaleźć w: Gillette i Sayad 1976; Hargreaves 1995; Liauzu 1996; MacMaster 1997; Sayad 2004; Talha 1989 i Zehraoui 1994.
} 
związani ze skrajną prawicą częstokroć ostrzegaja, że „przewrót islamistyczny [może] zwyciężyć w nowej wojnie stuletniej i sprowadzić na nas islam” (Hollender 1988).

Takie rasistowskie (lub islamofobiczne) dyskursy i wojenne obrazy zostają urzeczywistnione w konkretnych atakach, które maja na celu w sposób szczególnie zrytualizowany odeprzeć armię imigrantów. Ataki te mają swą genealogię w aktywizmie nacjonalistycznym oraz faszystowskim lat dwudziestych i trzydziestych, zwłaszcza w ruchu Action Française Charles'a Maurrasa; w tym przypadku uogólniony antysemityzm rozciagał się zarówno na Żydów, jak i na muzułmanów. Pod rządami Vichy muzułmanie, a zwłaszcza muzułmańscy nacjonaliści, byli internowani i deportowani na równi z Żydami, zarówno w metropolii, jak i na terytoriach Afryki Północnej. Podczas wojny francusko-algierskiej doszło do nagłego wzrostu skali przemocy wobec imigrantów, tak ze strony społeczeństwa, jak i policji. Choć głównym celem tej przemocy było rozbicie ruchu nacjonalistycznego, często dotykała ona bez wyjątku mężczyzn i kobiety z Afryki Północnej ${ }^{9}$. Skutkiem tej kolonialnej historii były okresowe „mordercze lata” (étés meurtriers) pomiędzy rokiem 1973 a 1983, podczas których zginęło prawie pięćdziesięcioro mężczyzn przybyłych z Afryki Północnej i ich dzieci (Aïchoune 1985). Tylko latem 1973 roku w Marsylii i okolicach zaatakowano pięćdziesięciu robotników z Algierii, z czego piętnastu zabito; ataki te znane były lokalnie jako ratonnade („polowanie na szczury”). W sposób przypominający sportową rozgrywkę (być może arystokratyczna tradycje polowania na lisy) grupa białych beaufs (skrót od beaux-frères, czyli „szwagrów” - francuski odpowiednik ,good ol' boys” - dosłownie „starych dobrych chłopców”) atakowała „szczura” (raton), biła go, niszczyła jego dokumenty czy odcinki z wypłata (w ten sposób czyniąc jego pobyt we Francji nielegalnym) i porzucała na pewną śmierć. Jednakże do wczesnych lat osiemdziesiatych rytualne ataki uległy pewnej zmianie: głównymi ofiarami nie byli już pracownicy-imigranci, lecz ,imigranckie” dzieci (niezależnie od ich faktycznego miejsca urodzenia), bawiące się na podwórkach pomiędzy blokowiskami. Dzieci nie były jednak ścigane przez grupy młodych mężczyzn; w snajperskim stylu strzelali do nich z okien sąsiedzi (głównie starsi, biali mężczyźni), używający nabojów .22 Long Rifle, które zwykle wykorzystywane są podczas polowań (Aïchoune 1985, 141-143).

Ważne jest to, by zwrócić tu uwage na sposób wyrażania rasizmu, nacjonalizmu i na sportowy charakter opisywanych ataków. Zmaskulinizowana przyjemność zdaje się być centralnym składnikiem rasistowkiej przemocy we Francji; w pewnych kontekstach miała też kluczowe znaczenie dla konstytuowania się białej męskości klasy robotniczej. Co więcej, opisane wyżej ataki wydają się stanowić akty ustanawiania ekskluzywistycznie rozumianego narodu francuskiego (Stolcke 1995). Choć intencje poszczególnych atakujących są w dużej

\footnotetext{
9 Zob. rozbudowane historie rasizmu ery kolonialnej i przemocy stosowanej wobec Algierczyków we Francji: zob. MacMaster 1997; Noiriel 1988 i Wihtol de Wenden 1991. Rozszerzone omówienie performatywności przemocy w konstytuowaniu się kategorii identyfikacji rasowej znaleźć można także w moim tekście: Silverstein 2008.
} 
mierze niezbadane, same ataki wpisują się w szerszą symboliczną historię i strukturę. Podarcie dokumentów stanowi reprezentację legalnego wydalenia z kraju; branie na celownik dzieci (a także, w Niemczech, domów) sygnalizuje wyłączenie [,imigrantów”] z narodowej rodziny i z prawnie sankcjonowanych sposobów reprodukcji społecznej. Jednakże, jak twierdzi Terence Turner (1995), rasistowskie ataki są w równej mierze aktami włączania (inkluzji), co wyłączania (ekskluzji). Zmarginalizowani (często bezrobotni) „biali Francuzi” zachowują się brutalnie, jak gdyby w ten sposób mieli ponownie wpisać się w społeczeństwo w roli obrońców rasowo określonego „narodu”, w imieniu którego zdają się (jak sami czasem twierdza) działać. Ekskluzywne męskie obywatelstwo jest zatem brutalnie odgrywane poprzez rasistowskie ataki.

Używając sformułowania Allena Feldmana (1991, 20), powiedzieć można, że odgrywanie beauf - męskiego nacjonalistycznego sprawstwa - poprzez przemoc w postkolonialnej Francji opiera się na „nowych pozycjach podmiotowości, [które] są konstruowane i interpretowane przez akty przemocy". Jednakże nie tylko męski podmiot - beauf - określany jest poprzez przemoc. Franko-maghrebska męska podmiotowość jest bowiem wytwarzana podobnie, w toku tych samych ataków rasistowskich, i zapośredniczona poprzez konfrontację państwem francuskim oraz jego agentami. Obok strzelanin z użyciem nabojów .22 Long Rifle we wczesnych latach osiemdziesiątych rozwinęła się druga rytualna forma ataku: nieuzasadnione użycie siły przez policję i ochroniarzy wobec młodych mężczyzn - „imigrantów” z banlieues. Wśród atakujących byli prywatni strażnicy i ochroniarze zatrudnieni w lokalnych supermarketach oraz na stacjach kolejowych, czyli w wydzielonych przestrzeniach państwa francuskiego na osiedlach mieszkalnych. Tak jak w przypadku osób atakujących za pomocą nabojów .22 Long Rifle, sprawcom tych ataków często uchodziło na sucho właściwe przewinienie - na drodze ugody przyznawali się do mniejszych wykroczeń lub też udawało im się uzyskać całkowite uniewinnienie (Aïchoune 1985).

W dużej mierze w reakcji na taką bezkarna, „prawomocną” przemoc z początku lat osiemdziesiątych młode osoby pochodzenia franko-maghrebskiego, tak mężczyźni, jak i kobiety, zaczęły mobilizować się zbiorowo, aby przeciwstawić się policji, co później zostało nazwane „ruchem Beurów”' ${ }^{10}$. Ruch ten wspierany był przez nowo wybrany socjalistyczny rząd François Mitterranda, który podkreślał „prawo do różnicy” w ramach francuskiej tożsamości,

10 Etnonim „Beur” przyjęty został we wczesnych latach osiemdziesiątych przez młode osoby pochodzenia frankomaghrebskiego w celu wskazania na ich podwójne oddzielenie: od ,arabskiej” kultury rodziców (często nacechowanej pejoratywnie), a także od normatywnej francuskości i od oczekiwań asymilacji kulturowej związanych z tą ostatnią. Termin ten jest zazwyczaj uważany za dwusylabowe odwrócenie słowa arabe według reguł gry językowej verlan, choć inni twierdzą, że może być akronimem frazy Berbères d'Europe (Aïchoune 1985). Pojęcie to zostało następnie przejęte przez francuskie media i akademię, zaś osoby pochodzenia franko-maghrebskiego szybko się od niego odcięły; dziś postrzegają one ruch Beurów albo jako klęskę polityczną, albo jako manipulację rządową. Obecnie w formie samoapelacji używa się słowa „rebeu” (pojedyncze odwrócenie arabe według verlan). W tym eseju używam terminu „Beur” tylko w odniesieniu do aktywistów pochodzenia franko-maghrebskiego i ich towarzyszy drogi z lat osiemdziesiątych. W innych przypadkach używam apelacji analitycznej „osoby pochodzenia franko-maghrebskiego” (ang. Franco-Maghrebi), w pełni zdając sobie sprawę, że termin ten nie oddaje lokalnych praktyk nazewniczych i że użycie łącznika angażuje bardziej anglo-amerykańskie sposoby rozumienia tożsamości, niż odpowiada na oczekiwania Republiki Francuskiej dotyczące wymazywania znaków etnicznych i religijnych z przynależności politycznej. 
zalegalizował stowarzyszenia imigranckie zakazane od 1939 roku i zapewnił fundusze na różnorodne działania kulturowe i antyrasistowskie. Aktywizm Beurów uzyskał również szerokie wsparcie od katolickich organizacji pomocy społecznej, a także od lokalnych grup żydowskich, stając się w ten sposób przestrzenią produktywnego dialogu pomiędzy religiami. Różnice pomiędzy Beurami a Żydami [,feujs’] stawały się coraz bardziej wyraźne po inwazji Izraela na Liban, a także w obliczu stopniowego utożsamiania się kilku działaczy Beurów (poprzez ich związki z trockistowskimi organizacjami politycznymi) ze sprawa palestyńską (zob. Boukhedenna 1987). Ruch Beurów ujmowany szerzej, z perspektywy sceny artystycznej i kultury masowej, wzbudził również fantazje o przekraczającej podziały rasowe tożsamości, wyrażanej przez beurowską figurę baba cool. Był to długowłosy miejski bandyta społeczny, którego wzorem był Majid, bohater popularnej powieści Mehdiego Charefa Le Thé au harem d'Archi Abmed (1983) i filmu pod tym samym tytułem.

Ruch Beurów był również impulsem do rozwoju polityki berberystycznej we Francji. Akademicy kabylscy i imigranckie grupy robotnicze aktywne we Francji od 1967 rekonstytuowały się jako stowarzyszenia kulturowe, przyciagając młodszych Beurów kursami prowadzonymi w języku berberskim (tamazight), a także kursami poświęconymi berberskim tradycjom tanecznym, muzycznym i teatralnym. Stowarzyszenia te stworzyły podstawy dla współczesnego aktywizmu Amazigh, który podtrzymuje dyskurs wielokulturowości i świeckości wbudowany w ruch Beurów; w jego wyniku stały się one (jak i ogólnie aktywizm Beurów) obiektem gniewu islamistycznych ruchów społecznych, które wyrosły we francuskich banlieues w latach dziewięćdziesiątych (zob. Kepel 1987).

Jednakże przez cały ten czas głównym bodźcem dla wojowniczej postawy Beurów była rasistowska przemoc skierowana bezpośrednio przeciwko osobom pochodzenia frankomaghrebskiego. Pierwszy niezależny ruch Beurów zapożyczył angielską nazwę Rock Against Police (RAP - Rock Przeciwko Policji) i organizował darmowe koncerty, by zwiększyć publiczna świadomość w kwestii zamordowania przez policję trzech chłopców pochodzenia franko-maghrebskiego w okresie czterech miesięcy poprzedzających tę inicjatywę. Drugi koncert, który odbył się 15 maja 1981 roku, miał miejsce na terenie kompleksu mieszkalnictwa publicznego Couzy na paryskim przedmieściu Vitry, a dokładnie w miejscu, gdzie młody Kader Lareiche, będący jedną ze wspomnianych ofiar, został zabity przez strażnika nocnego trzy miesiące wcześniej (Aïchoune 1985, 127-128; Jazouli 1992, 28). Z kolei zabójstwo działacza społecznego Abdenbiego Guemiaha przy użyciu naboju .22 Long Rifle doprowadziło do założenia Stowarzyszenia Gutenberg w listopadzie 1982, nazwanego tak na cześć osiedla na przedmieściu Nanterre, na którym powstało (Boubeker i Abdallah 1993, 65).

Pierwsze francuskie stowarzyszenie kulturalne kobiet pochodzenia frankomaghrebskiego powstało w podobnych okolicznościach w marcu 1981 na osiedlu Busserine, na obrzeżu Marsylii. Jego założycielka była siostrą Zahira Boudjlala, zabitego miesiąc wcześniej 
razem z Lahouarim Ben Mohammedem. Chociaż stowarzyszenie wyraźnie określiło jako swój cel dokumentowanie rasistowskich zabójstw, pierwszym jego działaniem był protest przeciwko deportacji Djamili, młodej mieszkanki Busserine, która została aresztowana podczas demonstracji po zabójstwie Lahouariego. Innymi słowy, ukonstytuowanie się podmiotowości politycznej kobiet ze społeczności Beurów było historycznie oparte na męskiej przemocy i przeciwdziałaniu tejże. Ten ruch kobiet mający na celu ochronę przed francuskim państwem swoich - dosłownie i w przenośni - braci odwraca w istocie standardowe relacje płci w banlienes. Czerpiąc z własnej idealizacji życia domowego w Afryce Północnej i muzułmańskiej moralności, to mężczyźni pochodzenia franko-maghrebskiego zazwyczaj przyjmują role obrońców kobiet; inaczej mówiąc, bronią swego honoru poprzez kontrolowanie seksualności swoich sióstr (i innych spokrewnionych z nimi kobiet). Co więcej, kobiety pochodzenia frankomaghrebskiego jako obrończynie mężczyzn kontrastują z męską podmiotowością polityczną Beurów opisaną poniżej - podmiotowością brutalnych mścicieli poległych „braci”.

Takie „nowe pozycje podmiotowości” uwidaczniały się w trakcie Marszu na Rzecz Równości i Przeciwko Rasizmowi zorganizowanego w 1983 roku (znanego potocznie jako Marche des Beurs), który był przełomowym i jednoczącym wydarzeniem dla „ruchu Beurów”. Marsz ten zmobilizował ponad 100000 demonstrantów od Marsylii po Paryż, będąc w dużej mierze odpowiedzią na „mordercze lato” poprzednich miesięcy. Według jednego z uczestników, Ahmeda Ghayeta, marsz ten ukształtował Beurów jako pewną konkretną polityczną i pokoleniową podmiotowość: „Powiedziałbym, że historia młodzieży ochrzczonej dziś mianem młodzieży z »banlieues«, a wcześniej ochrzczonej mianem »Beurów«, rozpoczęła się na Marszu w 1983 roku” (cyt. za: Bouamama, Sad-Saoud i Djerdoubi 1994, 40). Wydarzenie to zorganizowane zostało przez Association SOS Avenir Minguettes, którego dwudziestoletni przewodniczący, Toumi Djaidja, został poważnie ranny kilka miesięcy wcześniej, podczas próby mediacji z policja, która poszczuła psami grupę młodych mieszkańców Les Minguettes (w Lyonie). Uczestnicy i uczestniczki Marszu niosły transparenty upamiętniające młodych mężczyzn zabitych latem, napotykając na swojej drodze, w podmiejskim Vaulx-en-Velin (Lyon) i Nanterre (Paryż), zorganizowane lokalnie czuwania poświęcone pamięci mieszkańców zabitych w poprzednim roku (Jazouli 1992, 60). W ten sposób kształtowanie się Beurów jako między-przedmieściowego pokolenia politycznego stanowiło odpowiedź na morderstwa młodych mężczyzn z banlieues, którzy postrzegani byli przez działających w ich społecznościach aktywistów jako „bracia” [frères], spokrewnieni z nimi prawdziwymi, jak w przypadku Zahira Boudjlala, lub metaforycznymi więzami krwi (Bouamama i in. 1994, 50).

Choć wiele osób pochodzenia franko-maghrebskiego uczestniczyło w pokojowych działaniach, takich jak wyżej wspomniany marsz, inni uważali, że okazywanie biernej solidarności jest bezskuteczne i żądali „ceny krwi” [prix de sang] (Bouamama i in. 1994, 50). Ale jako że właściwy sprawca albo znajdował się w areszcie policyjnym, albo sam był policjantem 
i nie mógł zostać bezpośrednio ukarany przez mężczyzn będących krewnymi ofiary, członkowie społeczności podejmowali działanie zbiorowe, kierując swój „gniew” na policję jako taką, a także na symbole swego ekonomicznego wykluczenia w cités. Latem 1981 po policyjnym nalocie w Cité de la Cayolle w Marsylii, w trakcie którego ranne zostały kobiety, dzieci i osoby starsze, młodzi mieszkańcy podłożyli ogień w centrach handlowych i na posterunkach policji w całej okolicy. W tym samym czasie w Lyonie uczestnikom strajku głodowego, którzy protestowali przeciwko deportacjom młodych osób pochodzenia frankomaghrebskiego, nie udało się doprowadzić do zmiany prawa odpowiadającego za owe deportacje. Niedługo później młoda kobieta z sąsiedniego Saint-Dizier została deportowana do Algierii, zaś Les Minguettes w rezultacie wybuchło serią brutalnych konfrontacji między młodymi mężczyznami a policją. Doszło do około 250 incydentów, w ramach których grupy chłopców, głównie pochodzenia franko-maghrebskiego (ale także innych mieszkańców banlieues), kradły samochody, wciagały policję w pościgi, a potem porzucały i paliły skradzione pojazdy.

Choć te „rodea” (jak je lokalnie nazywano) nacechowane były przyjemnością czy wręcz przypominały sport, były one często (choć z pewnościa nie zawsze) rozumiane przez uczestników jako ćwiczenia w specyficznej sprawczości, określanej przez przemoc w banlieues. Według pewnego mieszkańca i lokalnego aktywisty, Djamela, „młodzi zaczęli być agresywni od czasu prowokacji policyjnych, bo nie rozumieli agresji policji w stosunku do nich samych. Rodeo miało być odpowiedzią na wszystko, przez co przeszli oni i ich rodzice [...]. Gniew, który w sobie nosili, był kierowany na samochody" (cyt. za: Jazouli 1992, 21-22). Dwa lata później podobne konfrontacje w sąsiednim Venissieux (Lyon) doprowadziły do trwającej tydzień okupacji osiedla przez oddział składający się z czterech tysięcy policjantów. W tym samym roku młodzi mężczyźni z cité Monmousseau w Les Minguettes brutalnie starli się z policja po tym, jak ci ostatni wkroczyli do mieszkania, w którym miały znajdować się skradzione przedmioty. W tych starciach z policją i z państwem francuskim jako całością męska podmiotowość Beurów opierała się nie tylko na pozycji mężczyzn jako obiektów przemocy, lecz także na ich roli sprawców przemocy, mścicieli swych „braci” i obrońców swych „rodziców”.

Ta forma sprawczej podmiotowości została odziedziczona przez młodszych braci działaczy beurowskich, którzy na początku lat dziewięćdziesiątych doświadczyli jeszcze większej marginalizacji w stosunku do tego, co udało się wypracować ich rodzicom, oraz głębokiego rozczarowania w związku z porażką polityki wielokulturowej tożsamości przypisywanej ruchowi Beurów. W powtarzających się brutalnych konfrontacjach pomiędzy młodymi z cités a policją brały udział głównie lokalne grupy, przekraczające podziały religijne, etniczne i rasowe oraz reagujące na zabicie jednego ze swych „braci” przez przedstawicieli państwa. Do starć pomiędzy młodzieżą a oddziałami prewencyjnymi policji (Compagnies 
Républicaines de Sécurité albo CRS) doszło na przykład w listopadzie 1990 roku w cité Mas-duTaureau na przedmieściu Vaulx-en-Velin w Lyonie po tym, jak jego dwudziestojednoletni mieszkaniec, Thomas Claudio, zginął w wypadku motocyklowym ścigany przez policję; w marcu 1991 w Sartrouville (Paryż) po zamordowaniu osiemnastoletniego Djamela Chettouha przez ochroniarza w supermarkecie Euromarché; i w maju 1991 w Val-Fourré po śmierci osiemnastoletniego Aïssy Ihicha, który udusił się w areszcie po tym, jak odmówiono mu podania jego lekarstwa na astmę. Tak jak po „rodeach” urządzanych w 1981 roku, odpowiedź rządu na te akty kontestacji polegała na bezpośredniej interwencji w codzienne życie społeczne w cités poprzez zwiększoną obecność policji, programy dla młodych i rozwiązania ekonomiczne wzorowane na Planie Marshalla.

Poprzez takie reakcje państwo francuskie w dużej mierze utwierdzało popularyzowana przez media i przemowy konserwatywnych kandydatów politycznych wizję, według której młodzi z banlieues znajdują się coraz bardziej „poza prawem”. Wielu francuskich socjologów, czasem również byłych aktywistów beurowskich, opisywało młodych z banlieues jako uczestników „kultury rozruchów”, charakteryzującej się ogólną amnezją historyczną i „nienawiścią" wymierzoną we wszystkie symbole państwa francuskiego bez wyjątku (Aïchoune 1991, 13). Jeśli Beurowie, jako hybrydyczne podmioty polityczne, reprezentowali utopijna przyszłość „mnogiej Francji”, propagowanej przez aktywistów beurowskich i polityków socjalistycznych, a młodzi obywatele pochodzenia franko-maghrebskiego służyli jako ikony tej wielokulturowej przyszłości (Boubeker i Abdallah 1993, 43), to młodzi z banlieues $\mathrm{w}$ latach dziewięćdziesiątych reprezentowali dystopijne przeciwieństwo tychże w postaci niebezpiecznej społecznej anomii. Przedstawiając w ten sposób cités, uważano, że wielokulturowa społeczność oparta na klasie rozpadła się na „grupy etniczne i terytorialne”, które wikłaja się w „codzienną endemiczna przemoc” i są zdolne w najlepszym wypadku do organizacji „rozruchów” przeciwko policji (Jazouli 1992, 141-42). Cités coraz częściej przedstawiane były przez policję i media jako „strefy bezprawia [zones de non-droit], w których prawo Republiki jest zupełnie nieobecne” (Le Monde, 7 września 1995). Ten sposób prezentowania cités i wynikająca z niego państwowa polityka oparta na ich dalszej sekurytyzacji trwały aż do fali przemocy w październiku-listopadzie 2005, a potem w reakcji na nią (zob. Silverstein i Tetreault 2006).

Celem niniejszych rozważań nie jest uzasadnienie islamofobicznego przedstawiania francuskich obywateli-muzułmanów jako ponadnaturalnie czy kulturowo skłonnych do przemocy, nie jest nim także wykazanie, że wszystkie brutalne zachowania są z zamierzenia polityczne, lecz raczej podkreślenie, że podmiotowe pozycje mężczyzn i kobiet zamieszkujących osiedla (Beurów, beaufs i bardziej ogólnie, mieszkańców banlieues) są konstytuowane w znacznym stopniu w wyniku zmaskulinizowanej przemocy i poprzez nią, a także zauważenie, że przemoc ta organizuje podmiejskie przestrzenie marginalizacji. Co 
więcej, moim celem jest wykazanie, że walka ta ma charakter silnie lokalny, zorientowany na konkretne warunki marginalizacji doświadczanej przez młodzież ze strony państwa oraz jego społeczno-ekonomicznych przedstawicieli i ikon. Ogólnie mówiąc, motywacją młodych z banlieues nie były globalne ideologie marksizmu czy islamizmu, nawet jeśli takie ruchy polityczne były i wciąż są obecne w dzielnicach, o których mowa. W tym sensie nie dziwi, że „rozruchy” przeciw policji obierały za swój cel nie tylko policyjne posterunki, ale także sale gimnastyczne, centra handlowe, szkoły i tym podobne instytucje związane z gospodarcza, polityczną i kulturową dominacją państwa. Ataki te pociagają za sobą zarówno akty zniszczenia, jak i okupacji czy zawłaszczenia, gdyż mieszkańcy wpisują się w te przestrzenie, przywłaszczając je sobie przez stosowanie graffiti i „tagowania”"11. Z kolei w przypadku równoległego rozwoju oddolnych działań, podejmowanych w cieniu niewydolnych instytucji, mieszkańcy po prostu zastępuja te miejsca swoimi własnymi.

\section{Wojny z terroryzmem}

Jak pisze Vincent Geisser (2009) w swojej pracy zatytułowanej Nowa islamofobia, pozorny społeczny chaos (dez)organizacji młodzieży z cités stał się źródłem niepokoju, ponieważ uważano, że stworzył on przestrzeń, w której pojawiły się organizacje „komunitarne”, zwłaszcza fundamentalistyczne grupy islamskie. Od czasu upadku ruchu Beurów i początku wojny domowej w Algierii załamał się monopol rządowych agencji państw Afryki Północnej na organizację i przekazywanie wiedzy o islamie oraz formach jego praktykowania. W miejscu tego monopolu prosperuje obecnie we Francji szeroka gama stowarzyszeń islamskich, struktur związanych z meczetami i organizacji aktywistycznych, które maja swój rodowód w różnych ruchach sufickich i salafickich, mających z kolei swoje źródło na Bliskim Wschodzie, w Azji Południowej i w Afryce Zachodniej (zob. Bowen 2009; Cesari 1994; Kepel 1987). Chociaż ich wierzenia i praktyki religijne są raczej zróżnicowane, wiele młodszych mężczyzn i kobiet pochodzenia franko-maghrebskiego dołącza do prozelitycznych grup islamskich i zamienia „tradycjonalizm” swoich rodziców na uwspółcześnione, uproszczone interpretacje Koranu oraz nauki hadisów.

Wobec transnacjonalizacji przemocy algierskiej wojny domowej powszechne lęki dotyczące „zbuntowanego pokolenia” z banlienes przełożyły się na konkretne niepokoje o franko-maghrebską młodzież z cités, ulegającą „pokusie dżihadu” (por. Pujadas i Salam 1995). Strach ten symbolizowały zwłaszcza dwie historie. Pierwsza z nich dotyczy nawrócenia Toumiego Djaidji, organizatora i ikony Marche des Beurs z 1983 roku, na neotradycyjna formę

\footnotetext{
11 Angielskie słowo tags odnoszące się do graffiti w formie podpisu, w szczególności identyfikującego autora lub grupę (także kryminalna), do której ten przynależy [przyp. tłum.].
} 
islamu w trakcie odsiadywania krótkiego wyroku w więzieniu. Druga historia wiąże się z udziałem Khaleda Kelkala, mieszkańca Mas-du-Taureau pochodzenia frankomaghrebskiego, w próbie zamachu bombowego w 1995 roku na linię kolejową prowadząca do Lyonu; zamach ten przypisany został Zbrojnej Grupie Islamskiej z Algierii. W oczach francuskich urzędników państwowych i komentatorów medialnych te dwie trajektorie naznaczyły narodziny trzeciego pokolenia imigrantów w latach dziewięćdziesiątych, opierającego się na transnarodowych powiązaniach pomiędzy młodymi autochtonami z francuskich banlieues i bojownikami islamistycznymi czy Berberami, którzy uciekli przed wojną domową w Algierii i zamieszkali we Francji (Silverstein 2004b, 174-183).

Niepokoje dotyczące możliwych powiązań osiedli z międzynarodową siecią terrorystyczna, mająca łączyć Algier z Kolonią, Sarajewem, Kabulem i Irakiem (por. Le Figaro, 16 sierpnia 1995), przybrały na sile, gdy w trakcie śledztwa po ataku na WTC aresztowano, pod zarzutem bycia „dwudziestym porywaczem z 11 września”, pochodzącego z Maroka Francuza, Zacariasa Moussaoui, a także po odkryciu, że kilku obywateli francuskich pochodzących z Afryki Północnej zasila szeregi Talibów w Afganistanie i „zagranicznych bojowników” bioracych udział w irackim powstaniu. W odpowiedzi na te wydarzenia, w ramach lokalnej francuskiej wojny z terroryzmem, próbuje się odzyskać kontrolę nad polami walki w cités i włączyć je z powrotem w państwowe ramy gospodarcze i polityczne. Wojna ta rozgrywana jest na dwóch frontach, które jednocześnie wzmacniają identyfikację osób pochodzenia frankomaghrebskiego jako podmiotów przede wszystkim muzułmańskich i sytuują tę podmiotowość w opozycji do francuskiej przynależności społeczno-politycznej. Po pierwsze, rząd francuski zwiększa częstotliwość interwencji i policyjny nadzór nad miejskimi peryferiami, usiłując wyraźnie odzyskać monopol na miejscowa przemoc. Siły bezpieczeństwa i agencje wywiadu wielokrotnie przeprowadzaja naloty [rafles] w cités, poszukując podejrzanych o terroryzm, włamując się do sal modlitewnych i miejsc spotkań stowarzyszeń. W odpowiedzi na zamachy bombowe latem 1995 roku rząd francuski aktywował plan antyterrorystyczny Vigipirate w celu podniesienia poziomu publicznej czujności. Opracowany w 1978 roku i po raz pierwszy wprowadzony w życie podczas wojny w Zatoce Perskiej w 1991 roku, plan ten działa w oparciu o logikę militarnego odstraszania; armia mobilizowana jest w celu strzeżenia szkół, węzłów komunikacji publicznej, budynków rządowych i centrów turystycznych. Plan pozostawał w mocy aż do ataków z 11 września, kiedy to podniesiono go na „wyższy” poziom ,intensywnej obserwacji” instytucji publicznych. Tak jak ustawa Patriot Act w USA, tak i wzmocniony plan Vigipirate wiązał się z ułatwieniem uzyskania nakazu przeszukania, a także sankcjonował powszechne kontrole tożsamości i przeszukiwanie dobytku w miejscach publicznych. Młodzi z Afryki Północnej są głównym celem takich „przypadkowych przeszukań” (contrôles au faciès), których efektem są niezliczone zatrzymania sądowe i aresztowania, a w przypadku imigrantów nieposiadających dokumentów - deportacje. W rezultacie takich kontroli tożsamości agenci 
bezpieczeństwa interpelują osoby pochodzenia franko-maghrebskiego jako potencjalnych islamistycznych terrorystów.

Te środki bezpieczeństwa są dodatkowo skupione na cités jako przestrzeniach potencjalnego terroryzmu. Na mocy planu Vigipirate z 1995 roku do już rozbudowanych podmiejskich sił bezpieczeństwa włączono 200 inspektorów w cywilu w celu „przeniknięcia do środowisk przestępczych” (L’Express, 9 listopada 1995). W 1999 roku socjalistyczny premier Lionel Jospin wzmocnił te środki, mobilizując dodatkowo siły 13000 osób w oddziałach prewencyjnych i 17000 oficerów żandarmerii militarnej w celu patrolowania tych samych „wrażliwych stref miejskich”. Wreszcie w 2003 minister spraw wewnętrznych spod znaku prawa i porządku, Nicolas Sarkozy jeszcze bardziej zwiększył liczbę oddziałów sił bezpieczeństwa w cités i przyznał im uprawnienia do przeszukiwania domów i pojazdów, docierając $w$ ten sposób do uprzednio niedostępnych miejsc (tak zwanych obszarów no-go). Próbując zniszczyć tajne meczety i stowarzyszenia związane z islamem, Sarkozy jednocześnie zdelegalizował zgromadzenia w wejściach, piwnicach i garażach publicznych blokowisk.

Po drugie, francuska wojna $z$ terroryzmem wiąże się z oficjalnym uznaniem islamu, które jest jednocześnie uznaniem czegoś, co ma zostać poddane kontroli. Rząd francuski próbuje przede wszystkim określić parametry praktyki islamskiej we Francji poprzez oficjalne zakazywanie noszenia chust w szkołach publicznych i stworzenie oficjalnych Francuskich Rad Wiary Muzułmańskiej (CFCM), które miałyby pośredniczyć pomiędzy francuskimi muzułmanami i państwem (Bowen 2006; Fernando 2005; Silverstein 2004a). Polityka ta stwarza instytucje i normy prawne, poprzez które rząd próbuje pogodzić praktykę islamską z francuską ideologia lä̌cité. Chociaż próby tworzenia takich ciał zarządzających miały miejsce od 1989 roku, tchnięto w nie nowe życie po 11 września, kiedy to Sarkozy postanowił zastapić Islam des caves („Islam garaży i piwnic”) łatwiejszym do kontrolowania „Islamem meczetów”. Jednakże kiedy znacząca liczba przedstawicieli Unii Islamskich Organizacji we Francji (UOIF), posiadającej rzekomo historyczne powiązania z egipskim Bractwem Muzułmańskim, zdobyła mandaty w wyborach w kwietniu 2003, Sarkozy zagroził wydaleniem z kraju imamów, których poglądy nie zgadzają się z prawem francuskim, a także zamknięciem ich meczetów.

Jak podkreśla Mayanthi Fernando (2005), te próby stworzenia oficjalnego islamu Francji (przeciwstawionego islamowi we Francji) zacierają różnicę pomiędzy społecznością muzułmańską definiowaną przez praktykowanie wiary (zwłaszcza uczęszczanie do meczetu) a tą definiowaną przez samoidentyfikację. W projekcie łączenia CFCM ze strukturami meczetowymi nie jest brana pod uwage wiara muzułmańska i jej praktykowanie zapośredniczone przez nieoficjalne formy organizacyjne lub praktyki prywatne, domowe. Co więcej, uciszana jest znaczna większość osób pochodzenia franko-maghrebskiego, które identyfikują się kulturowo jako muzułmanie, lecz nie praktykują aktywnie swojej religii. W ten 
sposób łączenie francusko-islamskiej reprezentacji z meczetami uprzywilejowuje starszych mężczyzn zarówno kosztem kobiet, jak i młodszych mężczyzn zaangażowanych w da'wa.

Ze względu na te procesy samoidentyfikacji i interpelacji państwowej osoby pochodzenia franko-maghrebskiego coraz częściej przedstawiają się publicznie jako muzułmanie, a ich przynależność do narodu francuskiego i lojalność wobec francuskiego państwa są następnie kwestionowane. Podczas gdy starsze formy identyfikacji i organizacji młodych w latach osiemdziesiątych i wczesnych latach dziewięćdziesiątych oparte były na współdzielonych cechach klasy i lokalności - na tym, że byli biednymi mieszkańcami marginalizowanych blokowisk - które zastępowały różnice rasowe i religijne, stanowiąc podstawę przekraczającej podziały rasowe identyfikacji Vinza z filmu La Haine, to praktyki prywatne i polityka państwowa sprzyjają nowemu urasowieniu i stosowaniu kategorii religijnych. Nie znaczy to, że lokalne kategorie urasowienia, jak rebeu, feuj czy renoi (czarnoskóry) nie były częścią słownika banlieues przed wojna domowa w Algierii, ale były to stosunkowo ruchome formy odniesienia, które wyrażały w równej mierze osobistą odrębność, co korzenie etniczno-religijne. Co więcej, solidarność między młodymi przekraczała te rasowe granice, a lokalne bandes (gangi) organizowały się głównie według miejsca zamieszkania. Nowe formy identyfikacji religijnej wyznaczaja jednak coraz bardziej ograniczone formy uspołecznienia, które, choć nie wykluczają przekraczania podziałów rasowych czy religijnych, każą interpretować lokalną walkę społeczną jako wyraz większego, transnarodowego konfliktu religijnego, co grozi tym, że może się on przerodzić w samospełniającą się przepowiednię.

Innymi słowy, kiedy osoby pochodzenia franko-maghrebskiego jako muzułmanie sa świadkami wydarzeń z 11 września, amerykańskiej okupacji Afganistanu i Iraku czy też trwającej przemocy w Izraelu/Palestynie, to w coraz większym stopniu widzą w nich lustrzane odbicie trudności, które oni sami przechodzą w swoim życiu codziennym. Pomimo oczywistych różnic dyplomatycznych i politycznych pomiędzy Francją a Stanami Zjednoczonymi i Izraelem, młodzi francuscy muzułmanie implicite uznają analogię między armią amerykańska, izraelskim IDF i francuskimi oddziałami prewencyjnymi policji. Innymi słowy, interpretuja oni na nowo swoje bitwy z francuskimi siłami prawa i porządku jako własną intifadę, jako opór przeciw siłom imperializmu. Jeśli ich starsi bracia i siostry postrzegali swoje walki jako z konieczności lokalne i osadzone w szerszym kontekście walk o prawa obywatelskie we Francji, to wielu dzisiejszych młodych pochodzenia franko-maghrebskiego postrzega się dodatkowo (jeśli nie przede wszystkim) jako osoby o transnarodowej podmiotowości muzułmańskiej, solidarne z uciśnionymi Palestyńczykami, Afgańczykami i Irakijczykami. Wieviorka (2007, 112) czyni następującą obserwację na temat tego, co nazywa „antysemityzmem getta” o globalnym zasięgu: „Doświadczenie muzułmanów [we Francji] staje się ilustracją tego, czego muzułmanie mają doświadczać na poziomie międzynarodowym, i jest stale kojarzone z wizjami dominacji izraelskiej nad Palestyńczykami czy przemoca, której ze 
strony Amerykanów doświadczają Irakijczycy". To skojarzenie między islamem a oporem przeciwko imperializmowi wzmacnia islamofilię lokalnej młodzieży i przyczynia się do przyspieszenia nawróceń na islam w banlieues jako formy „protestu społecznego” (Daynes 1999, 316).

Co więcej, taki zestaw sojuszy - który urasawia religię ponad klasą - wiąże się z odmiennym stosunkiem do innych urasowionych grup. Podczas gdy wcześniejsze walki jednoczyły wszystkich mieszkańców cités w opozycji do beaufs czy mieszczańskich paryżan (ci ostatni przyjęli style cités jako sposób swego własnego symbolicznego protestu), nowe pokolenie młodych z cités postrzega żydowskich współmieszkańców przede wszystkim jako przedstawicieli międzynarodowego imperializmu i, co zakrawa na ironię, antymuzułmańskiego państwa francuskiego, którego własna historia antysemickiej przemocy jest ignorowana. „Żydzi są przedmiotem niechęci po prostu dlatego, że mają jakoby unikać niesprawiedliwości i doświadczać szczególnie dobrego traktowania przez Francję jako niezasymilowani, lecz w pełni zintegrowani” (Wieviorka 2007, 109). Jak przejmująco podsumowują Wieviorka i jego współpracownicy $(2007,140)$, „ten antysemityzm getta stanowi historyczny paradoks: ci, którzy w przeszłości żyli w gettach [...] i doświadczyli rasistowskiej nienawiści, stają się dzisiaj, w imponującym zwrocie o sto osiemdziesiąt stopni, wyobrażonym źródłem zła, którego sami doświadczyli”.

\section{Powrót do „nowego antysemityzmu”}

To ta zmiana tożsamościowa pomaga wyjaśnić doniesienia o skokowym wzroście przemocy antysemickiej na początku pierwszej dekady dwudziestego pierwszego wieku i przypisanie jej po części francuskim muzułmanom mieszkającym w banlieues. Należy przyznać, że ów wzrost w statystykach trzeba do pewnego stopnia kwestionować, biorąc pod uwagę nowe wskazówki państwowe dotyczące zgłoszeń, które - zwłaszcza w szkołach, gdzie doszło do znacznej większości zgłoszonych wypadków - uprościły zbieranie danych z zakresu przestępstw związanych z rasą i prawdopodobnie doprowadziły do zgłaszania drobnych wypadków na szkolnym boisku jako przestępstw z nienawiści. Co więcej, skokowemu wzrostowi liczby zgłoszeń dotyczących antysemickiej przemocy towarzyszy jeszcze większy wzrost przemocy rasistowskiej i ksenofobicznej, zwłaszcza stosowanej wobec muzułmanów, który dokonał się po 11 września (Geisser 2003, 10-13). Narodowa Komisja Konsultacyjna Praw Człowieka (CNCDH) zanotowała w tej kwestii wzrost o 150\% w tym samym okresie 2003-2004, w którym częstotliwość ataków antysemickich wzrosła o 50\% (Le Monde, 21 marca 2005). Choć skala ataków antysemickich od tego czasu zmalała, nie stało się tak z przemocą wymierzoną przeciwko imigrantom i muzułmanom. 
Takie ujęcie pozwala ponownie przemyśleć porwanie i zabójstwo Ilana Halimiego, francuskiego Żyda i sprzedawcy telefonów komórkowych, przez wieloetniczną grupę młodych francuskich mężczyzn i kobiet z banlieues, zainicjowane przez młodego muzułmanina z Wybrzeża Kości Słoniowej. Wedle przekonującej argumentacji Briana Kluga (2003), „antysemityzm” powinien być definiowany jako przemoc, represje czy naigrawanie się wymierzone w Żydów jako Żydów. W tym sensie nie każdy atak na osoby żydowskiego pochodzenia musi być atakiem antysemickim, ponieważ wynikać może z zupełnie innej logiki ekonomicznej, rasowej czy też politycznej. Różnica ta jest kluczowa w rozróżnianiu antysyjonizmu (tj. platformy politycznej wymierzonej przeciwko jakiejś formie większego Izraela) od antysemityzmu (tj. rasizmu skierowanego przeciwko narodowi). W sprawie Halimiego mózg całego przedsięwzięcia twierdził, że motywacja porwania była wyłącznie finansowa - że Halimi wybrany został nie dlatego, iż był Żydem per se, ale dlatego, że uznano, iż jest bogaty. Lub, jak powiedział inny z porywaczy, „Ilan był Żydem, a Żydzi są bogaci” (Libération, 23 lutego 2006). Z tego względu atak nie może być włączony w narrację o „nowym antysemityzmie”, w który zaangażowani są muzułmanie i który związany jest z wydarzeniami w Izraelu/Palestynie. Zdaje się on raczej łączyć ze starszym antysemickim stereotypem Żydafinansisty, który przetrwał w historycznej retoryce francuskiej skrajnej prawicy i który następnie został zawłaszczony przez współczesną ideologię islamistyczną we Francji i za granicą oraz w pewnym stopniu stał się elementem zdroworozsądkowych przekonań w banlieues. Co więcej, jakakolwiek nie byłaby dokładna motywacja atakujących czy też ich osobiste (stare lub nowe) antysemickie przekonania, zabójstwo to odebrane zostało - tak przez francuskich Żydów, jak i przez państwo francuskie - jako przywołujące ducha odnowionego antysemityzmu. Zachęciło to kilka tysięcy Żydów do emigracji do Izraela (tak też robi rodzina Laury na koniec La Petite Jérusalem) i doprowadziło do zwiększonej mobilizacji społecznej przeciwko tej formie rasizmu. Wszystko to wskazuje, że we Francji może istnieć społeczna rzeczywistość antysemityzmu, niezależnie od natury danego ataku' ${ }^{12}$.

Co więcej, ataki takie jak ten na Halimiego wykazuja, że niektórzy młodzi francuscy muzułmanie dzielą przestrzeń ideologiczną z antysemicką ekstremalna prawica, która - o ironio - zbudowała swoja polityczna karierę na ksenofobicznej i islamofobicznej retoryce. Zamiast postrzegać akty przemocy, dokonywane przez młodych muzułmanów na Żydach i ich własności, jako porażkę republikańskiej integracji, jak interpretują to obserwatorzy tacy jak Brenner (2002) i Trigano (2003), można dowodzić, że jest to wyraźna oznaka ich zintegrowania

\footnotetext{
12 W 2004 roku głośno było o pewnym incydencie; młoda kobieta twierdziła, że została zaatakowana w paryskim pociagu podmiejskim przez grupę młodych ludzi, którzy narysowali jej swastykę na klatce piersiowej. Zdarzenie to wywołało głosy oburzenia wśród organizacji żydowskich $\mathrm{i}$ antyrasistowskich, a ze strony rządu padły publiczne przeprosiny, obietnice naprawienia krzywd i ostrzejszych wyroków za przestępstwa antysemickie. Kiedy kobieta ta przyznała później, że zmyśliła cały atak, prezydent Jacques Chirac powiedział publicznie, że to, co jest ważne, to fakt, że taki atak równie dobrze mógł mieć miejsce. W tym sensie atak ten, chociaż czysto wyobrażony, funkcjonował dalej jako fakt społeczny ze skutkami w prawdziwym świecie.
} 
z narodem francuskim, opartego zarówno na odrzuceniu różnicy kulturowej, jak i na afirmowaniu prowincjonalnej „Prawdziwej Francji” [pays réel], łączonej historycznie z katolickim antysemityzmem. Rzeczywiście, zgodnie ze starym (choć niekoniecznie nieprawdziwym) socjologicznym powiedzeniem, rasizm grupy imigrantów przejawiany wobec tych, którzy pojawili się w kraju później, może być wskaźnikiem ich asymilacji. W tym świetle warto zwrócić uwagę na moment, w którym w tekstach ukazujących się od 2002 roku larum na te tematy zaczęli bić akademicy tacy jak Brenner (2002), Trigano (2003), Taguieff (2004) czy Finkielkraut (2003). Prace te nie tylko są blisko powiązane z wojną z terroryzmem po 11 września i wezwaniem do większej regulacji islamizmu we Francji, lecz mogą także być odczytywane jako reakcja na integrowanie francuskich muzułmanów poprzez działające przy rządzie Francuskie Rady Wiary Muzułmańskiej, czyli organizacje, które chcą wprost, jak wyraził to były minister spraw wewnętrznych Nicolas Sarkozy, „posadzić islam przy stole Republiki” na tych samych warunkach, co Konsystorze Żydowskie ustanowione przez Napoleona. Trigano $(2003,15-17)$ otwarcie odrzuca porównania między „społecznościami” francuskich muzułmanów i Żydów jako współmiernych grup, które można uznawać za znajdujące się w stanie konfliktu. Nie byłoby czymś bezzasadnym opisać te alarmistyczne teksty jako wroga (jeśli nie islamofobiczna) reakcję na włączenie muzułmanów do grona pełnoprawnych obywateli francuskich.

\section{Wyobraźnia Amazighów}

Mimo wszystko wzajemna niechęć muzułmanów i Żydów we Francji, jako różnie usytuowanych, różnie zintegrowanych podmiotów politycznych, nie jest w żadnym razie nieunikniona. Filia tak jak i fobia może charakteryzować relacje międzyspołecznościowe we Francji. Czołowym przykładem tej pierwszej sa działania aktywistów berberskich (lub Amazigh) we Francji i Afryce Północnej, których związki z islamem, sekularyzmem i antysemityzmem są zupełnie niepodobne do zachowań francuskich muzułmanów przedstawianych w międzynarodowych mediach ${ }^{13}$. Jak wspomniałem wcześniej, kolonialni etnologowie traktowali Berberów jako wyjątkowo dopasowanych do cywilizacji francuskiej ze względu na ich rzekomo minimalną i powierzchowną islamskośćc ${ }^{14}$. Wielu dzisiejszych

\footnotetext{
13 Omawiam obszernie lä̈ité i filosemityzm Amazighów w innym tekście (Silverstein 2007).

${ }^{14}$ Aktywiści Amazighów - podobnie jak inni mówiący językami berberskimi w całej Afryce Północnej i diasporze - w istocie wcielają w swoje życie codzienne dużą różnorodność wierzeń i praktyk religijnych. Niektórzy bojownicy modlą się regularnie i przestrzegają muzułmańskich ograniczeń dietetycznych, podczas gdy inni posuwają się aż do usunięcia wszystkich odniesień do Boga w mowie i żywią niemal nieskrywaną pogardę dla wierzących w ich szeregach. Jednakże nawet najbardziej ekstremalni ateiści bronią na zewnątrz „tradycyjnych” form islamskiej praktyki Berberów, która, jak twierdza, jest elastyczna w swym zastosowaniu i idealnie zintegrowana z szerszymi formami kulturowymi, zaś nawet najbardziej bogobojni aktywiści Amazigh odmawiają poparcia islamistycznych argumentów dotyczących czynienia z religii priorytetu w życiu politycznym. Takie twierdzenia o kulturowo-religijnej odmienności Berberów zazwyczaj ignorują fakt historycznego udziału grup berberskich w ruchach religijnej reformacji
} 
aktywistów berberskich we Francji i Afryce Północnej - zorganizowanych w stowarzyszeniach kulturalnych, parasolowych ruchach społecznych (takich jak Mouvement Culturel Berbère w Algierii i Mouvement Amazigh w Maroko), partiach politycznych (takich jak Front des Forces Socialistes i Rassemblement pour la Culture et la Démocratie w Algierii) i organizacjach transnarodowych (Światowy Kongres Amazighów) - zachowuje się w sposób zgodny z tym kolonialnym stereotypem, akceptując heteropraksję i przedislamskie korzenie popularnych berberskich praktyk religijnych. Ogólnie rzecz ujmując, aktywiści ci odrzucają islam jako główny punkt zaczepienia swojej tożsamości, podkreślając w zamian historyczny (choć niejednoznaczny) rozdział między sferą religijną a polityczną $\mathrm{w}$ prawie zwyczajowym i w zakresie podejmowania decyzji wśród Berberów. Co więcej, odrzucają oni uogólniona politykę antysyjonistyczną (i okazjonalnie antysemicka) świata islamskiego, w zamian przyjmując dyskurs otwarcie filosemicki (jeśli nie prosyjonistyczny) (zob. Silverstein 2007). Krótko mówiąc, dla aktywistów Amazigh Żydzi stanowia „dobry przedmiot refleksji”, gdyż, podobnie jak totemiczne gatunki naturalne analizowane przez Claude’a Lévi-Straussa (1962), zapewniaja podstawy organizowania kategorii społecznych odnoszących się zarówno do Amazighów, jak i obcych. Żydzi funkcjonują dla bojowników Amazigh totemicznie, jako naród podobnie marginalizowany pod historyczną egida hegemonii arabsko-islamskiej na Bliskim Wschodzie i w Afryce Północnej. Ujmując tę kwestię bardziej ogólnie, aktywiści widzą w ruchu syjonistycznym wzór dla walki Amazighów: zwycięską kodyfikację i ochronę zagrożonego języka, a także zdobycie politycznej i terytorialnej autonomii poprzez ustanowienie państwa Izrael. Choć w żadnej mierze nie są agentami państwa izraelskiego, o co czasem oskarżają ich islamiści, bojownicy Amazigh próbuja aktywnie godzić populacje żydowskie i berberskie, a także opowiadają się publicznie za normalizacją stosunków z Izraelem. Poczynając od wczesnych latach dziewięćdziesiątych, delegacje artystów i intelektualistów francuskokabylskich odwiedzaja Izrael i publikują raporty ze swoich podróży w newsletterach oraz na blogach Amazighów, obejmujących swym zasięgiem zarówno Francję, jak i Afrykę Północna.

Być może najbardziej poruszający przykład filosemityzmu Amazighów, czy też identyfikacji przekraczającej podziały etniczne i religijne, zobaczyć można w mieście Goulmima w południowowschodnim Maroku i związany jest ze świętem maskaradowym znanym lokalnie jako Udayen Achour (Żydowska Ashura), w ramach którego berberscy uczestnicy dosłownie nakładają ,żydowskie twarze” i dokonują rytualnego odwrócenia ról etnicznych, religijnych, a czasem płciowych ${ }^{15}$. Festiwal ten ma miejsce miesiąc po Eid al-Adha i stanowi rytualne zamknięcie święta końca roku, kiedy to ostatnie, wysuszone kawałki mięsa zarżniętego barana

\footnotetext{
i oczyszczenia, zwłaszcza za czasów berberskich imperiów Almorawidów i Almohadów w Andaluzji, a także fakt, że wśród współczesnych bojowników islamistycznych znajdują się osoby posługujące się językami berberskimi.

15 Z powodu ograniczonego miejsca nie mogę tu przytoczyć pełnego etnograficznego opisu i analizy Udayen Achour. Błyskotliwą etnografię podobnej maskarady w Atlasie Wysokim znaleźć można u Hammoudiego (1993).
} 
są zjadane we wspólnym kuskusie. Po posiłku mieszkańcy miasta zbierają się poza jego murami, gdzie młodzi mężczyźni, nazywając się udayen („Żydami”), zakładaja groteskowe maski i stroje, mające na celu ukrycie ich tożsamości, zaś niektórzy zakładają na siebie nawet stroje kobiece i występuja jako kobiety - tudayen. Uczestnicy w przesadny sposób flirtują (taqrefeyt) ze sobą nawzajem, a także z młodymi kobietami oglądającymi karnawał z oddali. By ująć rzecz bardziej ogólnie, zachowują się i mówią w sposób skandaliczny, wyśmiewając zarazem lokalne autorytety religijne i państwowe, jak i bardziej marginalne postaci z życia miasta (na przykład żebraków, prostytutki czy narkomanów), co w kontekście codziennych norm społecznych byłyby właściwie niemożliwe.

$\mathrm{Na}$ pierwszy rzut oka maskarada ta powtarza schematy przedstawień opartych na odwróceniach, które można znaleźć w całej berberskiej Afryce Północnej, a historycznie odbywających się pomiędzy Eid i Aszura. Kolonialni obserwatorzy poszukujący pierwotnej „religii berberskiej” zazwyczaj, wzorem Frazera, łączyli te występy z pogańskimi rytuałami społecznego odnowienia, w których płodność ziemi była regenerowana przez symboliczna śmierć i odrodzenie boga rolnictwa czy przez wydalenie zła poprzez kozły ofiarne (Hammoudi 1993, 15-32; por. Laoust 1921, 254). Postaci Żydów i osób o czarnym kolorze skóry (ismakhen, „niewolników”) interpretuje się zazwyczaj jako przykłady takich kozłów ofiarnych; są oni zawsze przedstawiani przez muzułmańskich Berberów w taki sam groteskowy, zseksualizowany sposób, jak na festiwalu w Goulmimie. Z tego względu od czasu uzyskania niepodległości przez Maroko maskarady Berberów wywołuja gniew islamskich reformatorów, potępiających je jako „pozostałości pogaństwa (jabiliyya)”, grożące skażeniem codziennych zachowań społecznych i zniszczeniem wartości muzułmańskich (Hammoudi 1993, 89, 167).

Udayen Achour stanowi okrojona wersję tego rytuału, zmienionego przez aktywistów Amazigh w coś, co przedstawiane jest jako opiewanie kultury judeoberberskiej - a nie drwina czy symboliczne wydalenie. Tak jak kolonialni etnologowie oraz islamscy reformatorzy, lokalni bojownicy Amazigh podkreślaja przedislamską genealogię maskarady, a nawet przypisuja jej poczatki żydowskiemu rytuałowi wskrzeszonemu w ostatnim czasie przez aktywistów. Chociaż zdają oni sobie sprawę z umiejscowienia tego rytuału w islamskim kalendarzu księżycowym, oddzielają go od ofiary Eid lub szerszego świętowania Aszury jako święta muzułmańskiego Nowego Roku. Podkreślając żydowski charakter wydarzenia, witaja się rzekomo żydowskim pozdrowieniem „Tchafou”, śpiewają utwory, w których postaci żydowskie przywoływane są w celu odnowienia dopływu wody w lokalnej rzece, odbywaja pielgrzymki do starej dzielnicy żydowskiej (mellah) oraz umieszczaja na swoich kostiumach hebrajskie napisy i sześcioramienne gwiazdy. Dumnie opowiadaja, jak w roku 2000 młodzi w maskach sprowokowali lokalnego imama do nałożenia fatwy z powodu znaków nawołujących do zbliżenia z Izraelem, zapisanych zarówno po hebrajsku, jak i po arabsku. 
Nakładanie żydowskich masek służy zatem do wzmocnienia autoprezentacji aktywistów berberskich jako nowoczesnych kosmopolitów i jako Europejczyków poprzez solidaryzowanie się, jeśli nie wręcz utożsamianie się z Żydami. Taki filosemityzm (czy wręcz prosyjonizm) pomaga aktywistom odróżnić się od arabskich muzułmanów, przedstawianych zgodnie z negatywnymi zachodnimi stereotypami jako skłonnych do fundamentalizmu, terroryzmu i antysemityzmu. Poprzez swoje entuzjastyczne wsparcie dla laïcité aktywiści Amazigh prezentują się jako „dobrzy muzułmańscy” imigranci i najlepsi obrońcy Republiki Francuskiej. Pod tym względem filosemityzm Amazighów stanowi narodowy i transnarodowy projekt rasowej inkluzji, anty-antysemityzmu i kosmopolitycznego sekularyzmu oraz wyobrażonej identyfikacji ponad podziałami społecznymi, która zmienia mape globu w sposób uderzająco odmienny od retoryki ,zderzenia cywilizacji”.

Każda analiza współczesnej islamofobii i islamofilii, podobnie jak antysemityzmu i filosemityzmu, musi rozpoznawać momenty, w których kategorie analizy ulegają fragmentacji. Pozycje społeczne „muzułmanina” i „Żyda” we współczesnym, postkolonialnym, francuskim basenie Morza Śródziemnego wyłaniają się z długiej historii fantazji i przemocy, w której różne postaci identyfikowane (i identyfikujące się) dziś zgodnie z tymi religijnymi osiami, uznawanymi za oczywiste, były rozmaicie umieszczane vis-à-vis różnych państwowych praktyk wykluczenia i asymilacji. Prawne oddzielenie Żydów od muzułmanów, a później Arabów od Berberów, którego dokonały kolonialne administracje Afryki Północnej (rozróżnienie, które w większym stopniu odzwierciedlało społeczne kasty metropolii niż stan międzygrupowych interakcji w przedkolonialnych społecznościach północnoafrykańskich), zyskało status społecznego faktu dzięki odtworzeniu go w ramach politycznej nierównowagi sił w Algierii i Maroku po zdobyciu niepodległości, a także w ramach stosowanej wobec imigrantów we Francji polityki mieszkaniowej i policyjnej. Mimo to inwigilacja niektórych muzułmańskich podmiotów oraz traktowanie ich jako problemu ze względu na ich potencjalną skłonność do ekstremizmu religijnego nabrały aktualności, jak omawiam to wyżej, w kontekście prowadzonej od połowy lat dziewięćdziesiątych „wojny z terroryzmem”. We Francji ta autoprezentacja i, w dalszej kolejności, interpelacja osób pochodzenia franko-maghrebskiego jako „muzułmanów” leży u podstaw współczesnych deklaracji solidarności mieszkańców banlieues z okupowanymi Irakiem i Palestyną, a zatem i u podstaw wynikającej zeń antysyjonistycznej (i czasami antysemickiej) orientacji we współczesnej francuskiej polityce ulicy. Jednak nawet ta trajektoria, co tutaj podkreślam, jest silnie kontestowana: otwarty aktywizm Amazighów wciąż rzuca wyzwanie niekwestionowanej propalestyńskiej orientacji - która cechuje franko-maghrebską politykę - odpowiadając na antysemityzm swoją własną filosemicką i okazjonalnie islamofobiczną retoryką.

Wyróżnikiem Francji i jej postkolonialnych północnoafrykańskich peryferii pozostaje zatem niejednoznaczność identyfikacji i dezidentyfikacji, solidarności i wykluczenia, co wynika 
z faktu, że marginalizowane społeczności muzułmańskie są w różnych momentach traktowane jako wyobrażone obiekty narodowej odnowy lub antyimperialistycznego protestu, w innych zaś demonizowane jako sprawcy przemocy i barbarzyństwa, natomiast Żydzi oscylują tu pomiędzy byciem obiektem rasowego i religijnego wstrętu a statusem ikon kosmopolitycznej nowoczesności. Jeśli współczesna retoryka „wojny z terroryzmem” podzieliła Żydów francuskich $\mathrm{w}$ kontekście ich politycznego wsparcia dla Izraela i alarmizmu związanego z narodzinami „nowego antysemityzmu”, to służy ona także podziałowi Berberów i Arabów na „dobrych” i „złych” muzułmanów, który - zgodnie z krytyką Mahmooda Mamdaniego (2004) - wyznaczany jest przez to, czy społeczności te opowiadają się za prawami kobiet, homoseksualistów i Żydów. Współczesnym wyzwaniem stojącym przed hybrydycznymi - na wielu poziomach - podmiotami skupionymi wokół francuskiego basenu Morza Śródziemnego, jest znalezienie nowych przestrzeni solidarności i nowych sposobów identyfikacji, które pozwoliłyby uniknąć ekstremistycznej retoryki islamofobii i islamofilii, antysemityzmu i filosemityzmu, i umożliwiłyby stworzenie nowej wizji interakcji społecznych oraz przynależności poza biegunami miłości i nienawiści.

Wcześniejsza wersja niniejszego eseju opublikowana została jako „Kontekst antysemityzmu i islamofobii we Francji” („Context of Antisemitism and Islamophobia in France”) w Patterns of Prejudice 42(1), 2008: 126. Autor dziękuje wydawnictwu Taylor and Francis za pozwolenie na przedruk. Badanie ufundowane zostało po części przez szczodre granty z U.S. Institute of Peace i Fulbright-Hays Faculty Research Abroad Program. Autor pragnie podziękować za komentarze i propozycje do kolejnych wersji tekstu Johnowi Bunzlowi, Brianowi Klugowi, Barbarze Rosenbaum, Emmanuelowi Saadii, Andrew Shryockowi, anonimowemu recenzentowi z Indiana University Press i różnym uczestnikom konferencji oraz warsztatów organizowanych przez Koebner Center for German History Uniwersytetu Hebrajskiego w Jerozolimie, Austriackiemu Instytutowi Spraw Międzynarodowych, U.K. Faculty Forum for Israel-Palestine Peace i Warsztatowi Praw Człowieka na Uniwersytecie Chicago, gdzie przedstawiane były wcześniejsze wersje tego tekstu. 


\section{Wykaz literatury}

Ageron, Charles-Robert. 1960. „La France a-t-elle un politique kabyle”. Revue historique 223: 311-352.

Aïchoune, Farid (red.). 1985. La Beur Génération. Paris: Sans Frontière/Arcantère. . 1991. Nés en banlieue. Paris: Ramsay.

Aïdi, Hisham. 2002. „Jihadis in the Hood: Race, Urban Islam, and the War on Terror". Middle East Report 224: 36-43.

- 2003. „Let Us Be Moors: Islam, Race, and »Connected Histories«”. Middle East Report 229: 42-53.

Amselle, Jean-Loup. 2003. Afrmative Exclusion: Cultural Pluralism and the Rule of Custom in France. Tłum. Jane Marie Todd. Ithaca, New York: Cornell University Press.

Asad, Talal. 2006. „Trying to Understand French Secularism”. W Political Teologies: Public Religions in a Post-Secular World. Red. Henk de Vries i Lawrence E. Sullivan. New York: Fordham University Press.

Auslander, Leora. 2000. „Bavarian Crucifxes and French Headscarves: Religious Signs and the Postmodern European State". Cultural Dynamics 12(3): 283-309.

Bahloul, Joëlle. 1996. The Architecture of Memory. Cambridge: Cambridge University Press.

Balibar, Étienne i in. 2003. Antisémitisme: L’Intolérable chantage. Paris: La Découverte.

Bat Ye'or. 2002. Islam and Dhimmitude: Where Civilizations Collide. Madison, New York: Fairleigh Dickinson University Press.

- 2005. Eurabia: The Euro-Arab Axis. Madison, New York: Fairleigh Dickinson University Press.

Benbassa, Esther. 1999. The Jews of France. Tłum. M.B. DeBevoise. Princeton, N.J.: Princeton University Press.

Beriss, David. 1990. „Scarves, Schools, and Segregation: The Foulard Affair”. French Politics and Society 8: 1-13.

Bertrand, Louis. 1930 [1889]. Le Sang des races. Le Cycle africain. Paris: Albin Michel.

Borgé, Jacques i Nicolas Viasnoff. 1995. Archives de l'Algérie. Milan: Editions Michèle Trinckvel.

Bouamama, Saïd, Hadjila Sad-Saoud i Mokhtar Djerdoubi. 1994. Contribution à la mémoire des banlieues. Paris: Editions du Volga.

Boubeker, Ahmed i Mogniss H. Abdallah. 1993. Douce France: La Saga du movement Beur. Paris: Im'media.

Boukhedenna, Sakinna. 1987. „Nationalité: immigré(e)”. Paris: Editions l’Harmattan.

Bowen, John. 2005. „Commentary on Bunzl”. American Ethnologist 32(4): 524-525. - 2006. Why the French Hate Headscarves. Princeton, N.J.: Princeton University Press. . 2009. Can Islam Be French? Pluralism and Pragmatism in a Secularist State. Princeton, N.J.: Princeton University Press. 
Brenner, Emmanuel (red.). 2002. Les Territoires perdus de la République: Antisémitisme, racisme, et sexisme au milieu scolaire. Paris: Mille et Une Nuits.

Bullard, Alice. 2000. Exile to Paradise: Savagery and Civilization in Paris and the South Pacific, 17901900. Stanford, California: Stanford University Press.

Bunzl, Matti. 2005. „Between Anti-Semitism and Islamophobia: Some Thoughts on the New Europe". American Ethnologist 32(4): 499-508.

Cesari, Jocelyne. 1994. Etre musulman en France. Paris: Karthala.

Chaker, Salem. 1990. Imarighen ass-a (Berbères dans le Maghreb contemporain). Algiers: Editions Bouchene.

Charef, Mehdi. 1983. Le Té au harem d'Archi Abmed. Paris: Mercure de France.

Colonna, Fanny. 1975. Instituteurs algériens, 1883-1939. Paris: Presses de la Fondation Nationale des Sciences Politiques.

Cooper, Frederick i Ann Laura Stoler. 1997. Tensions of Empire: Colonial Cultures in a Bourgeois World. Berkeley: University of California Press.

Daynes, Sarah. 1999. „Processus de conversion et modes d'identifcation à l'islam: l'exemple de la France et des Etats-Unis". Social Compass 46(3): 313-323.

de Neveu, Edouard. 1846. Les Khouan: Ordres religieux chez les Musulmans d'Algérie. Paris: Guyot. de Tocqueville, Alexis. 1991 [1837-1847]. De la Colonie en Algérie. Red. Tzvetan Todorov. Bruxelles: Complexe.

Derderian, Richard. 2004. North Africans in Contemporary France: Becoming Visible. New York: Palgrave Macmillan.

Docteur X. 1891. Simples réflexions d'un colon Algérien. Paris: Hennequin.

Draï, Raphaël. 2001. Sous le signe de Sion: L'antisémitisme nouveau est arrivé. Paris: Michalon.

Duclos, Louis-Jean. 1972. „Berbers and the Rise of Moroccan Nationalism”. W Arabs and Berbers: From Tribe to Nation in North Africa. Red. Ernest Gellner i Charles Micaud. Lexington, Mass.: Lexington Books.

Einaudi, Jean-Luc. 2001. Octobre 1961: Un massacre à Paris. Paris: Fayard.

Fanon, Frantz. 1985. Wyklety lud ziemi. Tłum. Hanna Tygielska. Warszawa: PIW.

Feldman, Allen. 1991. Formations of Violence. Chicago: University of Chicago Press.

Fernando, Mayanthi. 2005. „Te Republic’s »Second Religion«: Recognizing Islam in France”. Middle East Report 35(2): 12-17.

Figueras, André. 1983. La France aux Français. Paris: Publications André Figueras.

Finkielkraut, Alain. 2003. Au Nom de l'autre: Réflexions sur l'antisémitisme qui vient. Paris: Gallimard.

Foucault, Michel. 1998. Trzeba bronić społeczeństwa. Tłum. Małgorzata Kowalska. Warszawa: KR.

Geisser, Vincent. 2009. Nowa islamofobia. Tłum. Ewa Cylwik. Warszawa: Instytut Wydawniczy Książka i Prasa. 
Gillette, Alain i Abdelmalek Sayad. 1976. L'Immigration Algérienne en France. Paris: Editions Entente.

Guénif-Souilamas, Nacira i Eric Macé. 2003. Les Féministes et le garçon Arabe. Paris: Editions l'Aube.

Guilhaume, Jean-François. 1992. Les Mythes fondateurs de l'Algérie française. Paris: Harmattan.

Hamelin, M. 1833. Notice sur Alger. Paris: Dentu.

Hammoudi, Abdellah. 1993. The Victim and Its Masks. Chicago: University of Chicago Press.

Hargreaves, Alec. 1995. Immigration, Race and Ethnicity in Contemporary France. London: Routledge.

Haroun, Ali. 1986. Le Septième wilaya. Paris: Seuil.

Hollender, Jean-Pierre. 1988. 2004, Tous Musulmans. Montpellier: Collectif Français d'Ailleurs.

Hyman, Paula E. 1998. The Jews of Modern France. Berkeley: University of California Press.

Jazouli, Adil. 1992. Les Années banlieues. Paris: Seuil.

Kepel, Gilles. 1987. Les Banlieues de l'Islam. Paris: Seuil.

Killian, Caitlin. 2003. „The Other Side of the Veil: North African Women in France Respond to the Headscarf Affair". Gender and Society 17(4): 567-590.

Klug, Brian. 2003. „The Collective Jew: Israel and the New Anti-Semitism”. Patterns of Prejudice 37(2).

Lacheraf, Mostefa. 1953. „La Colline oubliée ou les consciences anachroniques”. Le Jeune Musulman février 13.

Lakhdar, Mounia, Geneviève Vinsonneau, Michael Apter i Etienne Mullet. 2007. „Conversion to Islam among French Adolescents and Adults: A Systematic Inventory of Motives". International Journal for the Psychology of Religion 17(1): 1-15.

Laoust, Emile. 1921. „Noms et cérémonies des feux de joie chez les Berbères du Haut de l'Anti-Atlas". Hesperis 1(1-3): 3-66, 253-316, 387-420.

Larcher, Emile. 1903. Traité élémentaire de législation Algérienne. Vol. 1. Paris: Rousseau.

Lévi-Strauss, Claude. 1962. Le Totémisme aujourd'bui. Paris: Presses Universitaires de France.

Liauzu, Claude. 1996. Histoire des migrations en Méditerrané occidentale. Bruxelles: Complexe.

Lorcin, Patricia M.E. 1995. Imperial Identities. Stereotyping, Prejudice and Race in Colonial Algeria. London: I.B. Tauris.

Lucas, Philippe i Jean-Claude Vatin. 1975. L'Algérie des anthropologues. Paris: François Maspero.

MacMaster, Neil. 1997. Colonial Migrants and Racism: Algerians in France, 1900-1962. New York: St. Martin's Press.

Mamdani, Mahmood. 2004. Good Muslim, Bad Muslim: America, the Cold War, and the Roots of Terror. New York: Doubleday.

Mishani, Dror i Aurelia Smotriez. 2005. „What Sort of Frenchmen Are They? Interview with Alain Finkielkraut". Haaretz November 25. 
Moruzzi, Norma. 1994. „A Problem with Headscarves: Contemporary Complexities of Political and Social Identity". Political Theory 22(4): 653-672.

Noiriel, Gérard. 1988. Le Creuset français: Histoire de l'immigration XIXe-XXe siècle. Paris: Seuil.

Peace, Timothy. 2009. „Un antisémitisme nouveau? The Debate about a »New Antisemitism« in France". Patterns of Prejudice 43(2): 103-121.

Pujadas, David i Ahmed Salam. 1995. La Tentation du Jihad. Paris: J.C. Lattès.

Raspail, Jean. 2015. Obóz świętych. Tłum. Marian Miszalski. Warszawa: Wydawnictwo Fronda.

Rinn, Louis. 1884. Marabouts et Khouan. Étude sur l'Islam en Algérie. Algiers: Jourdan.

Rosenblum, Mort. 1988. Mission to Civilize: The French Way. New York: Doubleday.

Servier, André. 1923. L'Islam et la psychologie du Musulman. Paris: Challamel.

Sahli, Mohammed C. 1953. „La colline du reniement”. Le Jeune Musulman janvier 2.

Sayad, Abdelmalek. 2004. The Suffering of the Immigrant. Cambridge, U.K.: Polity.

Scott, Joan Wallach. 2007. The Politics of the Veil. Princeton, N.J.: Princeton University Press.

Shatz, Adam. 2005. „The Jewish Question”. New York Review of Books 52(14).

Silverstein, Paul A. 2004a. „Headscarves and the French Tricolor”. Middle East Report Online January 29. http://www.merip.org/

- 2004b. Algeria in France: Transpolitics, Race, and Nation. Bloomington: Indiana University Press.

- 2005. „Immigrant Racialization and the New Savage Slot: Race, Migration, and Immigration in the New Europe". Annual Review of Anthropology 34: 363-384.

- 2007. „Islam, Laïcité, and Amazigh Activism in France and North Africa”. W North African Mosaic: A Cultural Reappraisal of Ethnic and Religious Minorities. Red. Nabil Boudraa i Joseph Krause. Newcastle, U.K.: Cambridge Scholars Publishing.

- 2008. „Thin Lines on the Pavement: The Racialization and Spatialization of Violence in Postcolonial (Sub)Urban France". W Gendering Urban Space in the Middle East, South Asia, and Africa. Red. Martina Rieker i Kamran Asdar Ali. New York: Palgrave Macmillan: 169-206.

Silverstein, Paul i Chantal Tetreault. 2006. „Postcolonial Urban Apartheid”. Items and Issues 5(4): 8-15.

Smith, Craig S. 2004. „Europe Fears Islamic Converts May Give Cover for Extremism”. New York Times July 19.

Sternhell, Zeev. 1986. Neither Right nor Left: Fascist Ideology in France. Princeton, N.J.: Princeton University Press.

Stolcke, Verena. 1995. „Europe: New Boundaries, New Rhetorics of Exclusion”. Current Anthropology 36(1).

Stora, Benjamin. 1991. La Gangrène et l'oubli: La mémoire de la guerre d'Algérie. Paris: La Découverte. 
2006. „The Algerian War in French Memory: Vengeful Memory's Violence”. W Memory and Violence in the Middle East and North Africa. Red. Ussama Makdisi i Paul A. Silverstein. Bloomington: Indiana University Press: 151-174.

Talha, Larbi. 1989. Le Salariat immigré devant la crise. Paris: Editions du CNRS.

Taguieff, Pierre-André. 2004. Rising from the Muck: The New Anti-Semitism in Europe. Tłum. Patrick Camiller. Chicago: Ivan R. Dee.

Trigano, Shmuel. 2003. La Démission de la République: Juifs et Musulmans en France. Paris: Presses Universitaires de France.

Turner, Terence. 1995. „Comment on Verena Stolcke, »Europe: New Boundaries, New Rhetorics of Exclusion «". Current Anthropology 36(1).

van Vollenhoven, Joost. 1903. Essai sur le fellah Algérien. Paris: Rousseau.

Vidal, Dominique. 2003. Le Mal-Etre juif: Entre repli, assimilation et manipulations. Marseille: Agone.

Whitlock, Craig. 2006. „Trial of French Islamic Radical Sheds Light on Converts’ Role”. Washington Post January 1.

Wieviorka, Michel. 2007. The Lure of Anti-Semitism: Hatred of Jews in Present-Day France. Tłum. Kristin Couper Lobel i Anna Declerck. Leiden: Brill.

Wihtol de Wenden, Catherine. 1991. „North African Immigration and the French Political Imaginary". W Race, Discourse and Power in France. Red. Maxim Silverman. Brookfeld, Vt.: Grower Publishing Co.

Zehraoui, Ahsène. 1994. L'Immigration: de l'homme seul à la famille. Paris: CIEMI/Harmattan. 
Paul A. Silverstein - Antropolog. Zajmuje się związkami imigracji, rasy i nacjonalizmu w kontekście kolonialnym i postkolonialnym. Jest autorem książki Algeria in France: Transpolitics, Race, and Nation (Bloomington: Indiana University Press, 2004).

\section{DANE ADRESOWE:}

Reed College, Portland USA

EMAIL: paul.silverstein@reed.edu

FINANSOWANIE: Tekst przetłumaczony w ramach projektu badawczego, który został sfinansowany ze środków Narodowego Centrum Nauki przyznanych na podstawie decyzji numer DEC-2011/03/B/HS1/01693.

CYTOWANIE: Silverstein, Paul. 2017. „Fantazja i przemoc wyobraźni religijnej: islamofobia i antysemityzm we Francji i Afryce Północnej.” Praktyka Teoretyczna 4(26): 153-185

DOI: $10.14746 /$ prt.2017.4.6

AUTHOR: Paul A. Silverstein

TITLE: The Fantasy and Violence of the Religious Imagination: Islamophobia and AntiSemitism in France and North Africa

ABSTRACT: The article attempts to trace the changes in French anti-Islam rhetoric and to situate it in the broader context of the (post)colonial history of assimilation policies in France. The author sets out from the question of the relation between this violence and the formation of ethno-religious difference. He describes the changes in political and cultural identity within French Muslim communities. Contemporary Islamophobia, which is evident in the media as well as in state policy, is juxtaposed with anti-Semitic discourse, in which the question of assimilation plays an important role. The Islamophobic and anti-Semitic narratives concerning the prospects of assimilation are used to demarcate which ethnic groups may be included in the national community and which are seen as genuinely alien.

KEYWORDS: Islamophobia, anti-Semitism, France, North Africa, Assimilation, violence State 